Review

\title{
New Insights to Adenovirus-Directed Innate Immunity in Respiratory Epithelial Cells
}

\author{
Cathleen R. Carlin
}

Department of Molecular Biology and Microbiology and the Case Comprehensive Cancer Center, School of Medicine, Case Western Reserve University, Cleveland, OH 44106, USA; cathleen.carlin@case.edu; Tel.: +1-216-368-8939

Received: 24 June 2019; Accepted: 19 July 2019; Published: 25 July 2019

check for updates

\begin{abstract}
The nuclear factor kappa-light-chain-enhancer of activated B cells (NFkB) family of transcription factors is a key component of the host innate immune response to infectious adenoviruses and adenovirus vectors. In this review, we will discuss a regulatory adenoviral protein encoded by early region 3 (E3) called E3-RID $\alpha$, which targets NFKB through subversion of novel host cell pathways. E3-RID $\alpha$ down-regulates an EGF receptor signaling pathway, which overrides NFKB negative feedback control in the nucleus, and is induced by cell stress associated with viral infection and exposure to the pro-inflammatory cytokine TNF- $\alpha$. E3-RID $\alpha$ also modulates NFkB signaling downstream of the lipopolysaccharide receptor, Toll-like receptor 4 , through formation of membrane contact sites controlling cholesterol levels in endosomes. These innate immune evasion tactics have yielded unique perspectives regarding the potential physiological functions of host cell pathways with important roles in infectious disease.
\end{abstract}

Keywords: adenovirus; early region 3; innate immunity; NFkB

\section{Introduction}

Adenoviruses have proven to be invaluable experimental tools contributing to many breakthrough discoveries, including mRNA splicing and antigen presentation to $\mathrm{T}$ cells [1,2]. The finding that adenovirus type 12 caused cancer in hamsters in a laboratory setting was the first example of oncogenic activity by a human virus [3]. Although adenoviruses have not been linked to human tumors, they have led to many advances in cancer biology, particularly in the field of tumor suppressors [4]. The study of host cellular pathways required for the adenovirus life cycle, and host restriction factors limiting its replication, has led to many significant advances in eukaryotic cell and molecular biology [5-8]. Adenovirus early region 3 (E3) gene products in particular have been powerful tools for discovering new mechanisms in the field of intracellular membrane trafficking [9-11]. Interactions between adenovirus E3 proteins and components of the host immune system have also revealed important insights into immune evasion tactics that are widely employed by intracellular pathogens [12,13]. In this review, we describe several new host cell pathways linking E3 to pro-inflammatory NFkB signaling in respiratory epithelial cells.

\section{Human Adenoviruses}

Human adenoviruses were first isolated from adenoid tissues removed from healthy children in 1953 [14]. A total of 90 genotypes divided into seven subgroups (A-G) have now been identified, including the original 51 serotypes and emergent recombinant species associated with recent outbreaks of adenovirus disease [15-17]. Adenovirus infections commonly present with mild respiratory or gastrointestinal symptoms in children under the age of five [18]. Other clinical manifestations include keratoconjunctivitis, hepatitis, and myocarditis [19]. Although most infections are self-limiting, 
periodic adenovirus outbreaks can pose significant health risks in people with no known predisposing conditions [20-22]. For instance, acute respiratory disease (ARD) is a serious and frequently fatal condition caused by adenovirus infections during conditions of crowding and stress [12,13,23]. Adenoviruses are also emerging as significant pathogens associated with high morbidity and mortality in individuals with weakened immune systems such as transplant patients, and people with existing respiratory or cardiac disease [18,24-28]. Currently, there are no FDA-approved drugs that are adenovirus-specific [29]. Although the antiviral drug cidofovir is used in transplant patients with probable adenovirus disease, the potential benefit of cidofovir therapy must be weighed against a relatively high risk of nephrotoxicity [30,31]. Brincidofovir is a lipid conjugate of cidofovir with increased antiviral potency against adenovirus and other double-stranded DNA viruses, which does not appear to be nephrotoxic [32]. Although brincidofovir is not yet FDA-approved, the drug is available for clinical use in transplant patients with suspected adenovirus disease through an expanded use protocol (https://www.clinicaltrials.gov/ct2/show/NCT02596997). A vaccine for adenovirus types 4 and 7 has been licensed for use by the US military because of high potential for ARD [33]. Recent public health concerns have raised the issue of whether the adenovirus vaccine should also be made available to the general public [34].

Adenoviruses are non-enveloped icosahedral viruses with a non-segmented double-stranded (ds) DNA genome that is approximately 36-kb in size [23,35,36]. The vertices of the icosahedral adenovirus capsid are comprised of a pentameric penton base and trimeric fiber proteins that mediate viral attachment and internalization [37]. Adenoviruses encode approximately 40 genes, which are read from both strands of the viral DNA [23,35,36]. The adenovirus life cycle is separated into an early and a late phase by the DNA replication process [23]. The early transcription units (E1, E2, E3, E4) mainly encode non-structural, regulatory proteins that are necessary for DNA synthesis, activate other virus genes, and prevent premature death of the infected cell by host innate and adaptive immunity defenses [36]. E3 transcripts produce several proteins with the capacity to promote persistent infections by modulating host immune responses [9]. Although they have been studied primarily in group $\mathrm{C}$ adenoviruses (HAdV-C2 and $\mathrm{HAdV}-\mathrm{C} 5$ ), these immunomodulatory proteins are conserved across all (E3-RID $\alpha$ or E3-10.4K, E3-RID $\beta$ or E3-14.5K, and E3-14.7K), or a great majority (E3-19K) of adenovirus species [38]. Other E3 products, such as the secreted $49 \mathrm{~K}$ protein encoded by group D adenoviruses, are uniquely expressed [39]. The late phase of the adenovirus life cycle is focused on production of structural proteins to package newly replicated viral DNA [23]. Once assembled in the nucleus, viral progeny are released by cell lysis through autophagy and autophagy-triggered caspase activity [40].

Adenovirus vectors have been extensively developed for gene therapy, as vaccines, and for cancer therapy over the past few decades, accounting for approximately a quarter of gene therapy clinical trials world-wide [41,42]. However, adenovirus vectors activate the innate immune system, representing a major barrier to the effective use of these agents in gene correction applications [12,13]. On the other hand, the innate immune response to adenovirus is a potentially useful attribute for vaccine development and cancer immune therapy [12]. This has motivated intensive efforts to understand the molecular basis of adenovirus-induced innate immunity, and how the virus strikes a balance between the elimination of virus and immune-mediated tissue injury [43]. These opposing regulatory mechanisms are primarily mediated by viral cell entry, early adenovirus proteins, and two virus-associated non-coding RNAs VA-I and VA-II [13]. Many of these mechanisms converge on the nuclear factor kappa-light-chain-enhancer of activated B cells (NFkB) pathway [12,13,44].

\section{Adenoviral Cell Entry and Innate Immunity}

Viral cell entry requires interactions between the virus and two sets of host cell receptors. The first interaction is mediated by the knob domain of fiber proteins binding to the coxsackievirus adenovirus receptor (CAR) for all serotypes except those belonging to group B, which bind the CD46 complement regulatory protein $[45,46]$. Some serotypes also utilize sialic acid-containing glycoproteins, 
as primary receptors in addition to CAR [47,48]. This is followed by a secondary interaction between a motif in the penton base protein and the RGD (Arginine, Glycine, and Aspartate) domain of $\alpha \mathrm{V}$ integrins [49]. Adenoviruses invade the lumen of the digestive and respiratory tracts. Paradoxically, adenovirus receptors are normally located on basolateral membranes of epithelial cells lining those tissues, representing a significant barrier to infection from the apical surface facing the lumen [50]. However, the initial innate immune response in alveolar macrophages appears to induce two pathways that regulate the epithelial polarity of these host cell receptors. The first pathway involves production of an alternatively spliced form of $C A R\left(C A R^{\mathrm{Ex} 8}\right)$ that is specifically targeted to the apical surface, as opposed to $\mathrm{CAR}^{\mathrm{Ex} 7}$ found on basolateral membranes (Figure 1a) [51]. This process is regulated by exposure to the proinflammatory cytokine and neutrophil chemoattractant IL-8, which binds CXCR1 and CXCR2 receptors located on apical epithelial surfaces. IL-8 binding induces an Akt/S6K (Serine/threonine-protein kinase) intracellular signaling pathway in epithelial cells, culminating in de novo protein synthesis and apical membrane targeting of $\mathrm{CAR}^{\mathrm{Ex} 8}$ [52]. Adenovirus entry into the epithelium appears to be further enhanced by neutrophils recruited to the apical surface through their interactions with $\mathrm{CAR}^{\mathrm{Ex} 8}$ [52]. In the second pathway, IL-8 activates a Src kinase-dependent mechanism causing apical membrane recruitment of the focal adhesion scaffolding protein paxillin (Figure 1a) [53]. Paxillin then appears to either function in apical trafficking of $\alpha \mathrm{v} \beta 3$ integrin, or as a component of a mechanism for retaining $\alpha \mathrm{v} \beta 3$ on the apical membrane [53]. Epithelial remodeling of $\alpha v \beta 3$ polarity subsequently enables apical binding and infection with adenovirus following binding to the primary adenovirus receptor $\mathrm{CAR}^{\mathrm{Ex} 8}$ [53].

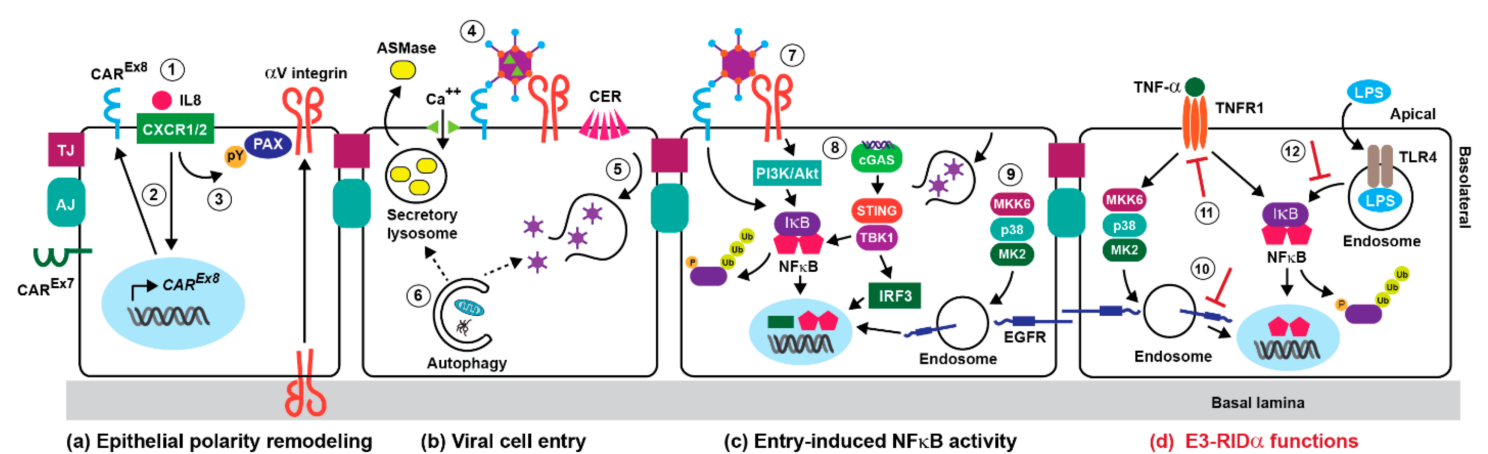

Figure 1. Adenovirus-directed innate immunity through nuclear factor kappa-light-chain-enhancer of activated B cells (NFKB). (a) Adenovirus induces host cell secretion of IL-8 (1), which regulates epithelial polarity of $\operatorname{Car}^{\mathrm{Ex} 8}$ (2) and $\alpha \mathrm{V}$ integrins (3), allowing adenovirus entry from apical surface of respiratory epithelial cells. (b) Host cell receptor binding also unmasks the viral membrane lytic protein-VI (green triangle), which activates a membrane repair system leading to the generation of plasma membrane ceramide lipids (4). Ceramides promote virus internalization and endosomal membrane penetration (5). Viral cell entry is also enhanced by elevated levels of autophagy via hypothetical mechanisms discussed in the text (6). (c) Adenovirus binding to host cell receptors elicits a first wave of NFKB activity (7). Endosomal penetration also contributes to NFKB activity through a cGAS-STING cytosolic DNA sensing pathway (8), and a p38-MAPK signaling cascade capable of activating EGFR (EGF receptor) stress responses (9). (d) In this review we discuss evidence suggesting that E3-RID $\alpha$ regulates NFkB activity occurring downstream of TNF- $\alpha$, by antagonizing stress-induced EGFR signaling in endosomes (10), and promoting post-internalization TNFR1 sorting to lysosomes (11); and downstream of LPS, by limiting cholesterol-dependent TLR4 signaling from endosomes (12).

Internalized virions have been shown to co-localize with some endocytic markers, chiefly for early endosomes [54,55]. It was also known that adenovirus uncoating and release of the viral membrane lytic protein-VI were necessary to penetrate cell membranes, allowing the virus access to the cytoplasm [56]. However, the identity of the compartment mediating escape to the cytosol was elusive, until recent studies identifying a role for an evolutionarily conserved physiological process for repairing membrane 
damage [57]. These studies revealed that adenovirus undergoes partial uncoating exposing protein-VI, upon mechanical cues from CAR and $\alpha \mathrm{v} \beta 3$ integrin viral receptors [58,59]. Protein-VI subsequently induces small plasma membrane lesions, stimulating calcium influx and plasma membrane fusion of secretory lysosomes, which both repairs membrane damage and releases acid sphingomyelinase (ASMase) into the extracellular space (Figure 1b) [57,58]. ASMase then converts plasma membrane sphingomyelin into ceramide lipids, which enhances virus endocytosis and protein-VI-mediated membrane rupture (Figure 1b) [58]. Studies have also revealed that early adenovirus gene expression and virus production were both enhanced in respiratory epithelial cells with elevated autophagy, which is an important adaptive response to high oxygen pressure in the airway [60,61]. Although the role of autophagy in the early stages of infection is not currently known, it could maintain the homeostasis of the endosome/lysosome pathway by repairing endosomes that have been damaged by protein VI-mediated membrane rupture (Figure 1b) [62]. Alternatively, autophagy could participate in the plasma membrane repair process driving endocytic uptake of the virus [63]. Serotype 7 belonging to adenovirus group B escapes from late endosomes/lysosomes, suggesting that the primary viral receptor CD46 initiates viral uptake through a different mechanism [64].

As with other viruses such as HSV-1, NFkB activation appears to occur in waves that presumably induce different patterns of gene expression over the course of an acute adenovirus infection [65]. Capsid binding to host cell receptors represents the earliest mechanism for activating NFKB signaling during an acute infection (Figure 1c). For instance, the interaction between the adenovirus fiber and CAR has been reported to elicit intracellular signaling leading to cytokine expression in cultured human respiratory epithelial cells [66]. It has also been demonstrated that adenovirus vectors activate a phosphoinositide 3-kinase (PI3K)/Akt signaling pathway contributing to NFkB-dependent cytokine expression in cultured epithelial cells, following binding to $\alpha \mathrm{V}$ integrins [67]. Once the virus has been internalized, endosomal escape activates another set of signaling pathways regulating host cell gene transcription before the onset of viral gene expression. Cytosolic adenovirus DNA is recognized by cyclic GMP-AMP synthase (cGAS), a DNA sensor that produces cyclic guanine-adenine dinucleotide (cGAMP) (Figure 1c) [68]. cGAMP then induces STING (Stimulator of interferon genes), a signaling molecule associated with the endoplasmic reticulum (ER) that activates IRF3 and NFKB transcription factors through an interaction with the IKK (inhibitor of NFKB kinases)-like kinase TBK1 (Figure 1c) [69]. Incoming adenovirus particles also activate $\mathrm{p} 38$-MAPK and its downstream effector MAPKAP kinase 2 (MK2), by a mechanism that is dependent on the p38-MAPK kinase MKK6, but independent of integrin-mediated cell signaling (Figure 1c) [70]. Capsid-induced p38-MAPK signaling could be activated as a response to the plasma membrane repair pathway mediating viral cell entry [71]. In addition to enhancing microtubule-mediated targeting of virus to the nuclear pore, p38-MAPK signaling has been linked to early inflammatory responses provoked by virus penetration of the endosome [70,72]. However, exactly how the p38-MAPK signaling cascade regulates NFKB signaling during an adenovirus infection was unknown. Our recent studies have suggested the involvement of a stress-activated EGFR (EGF receptor) signaling pathway, resulting in the stabilization and enhanced activity of nuclear NFKB in respiratory epithelial cells in vitro (Figure 2) [73]. 


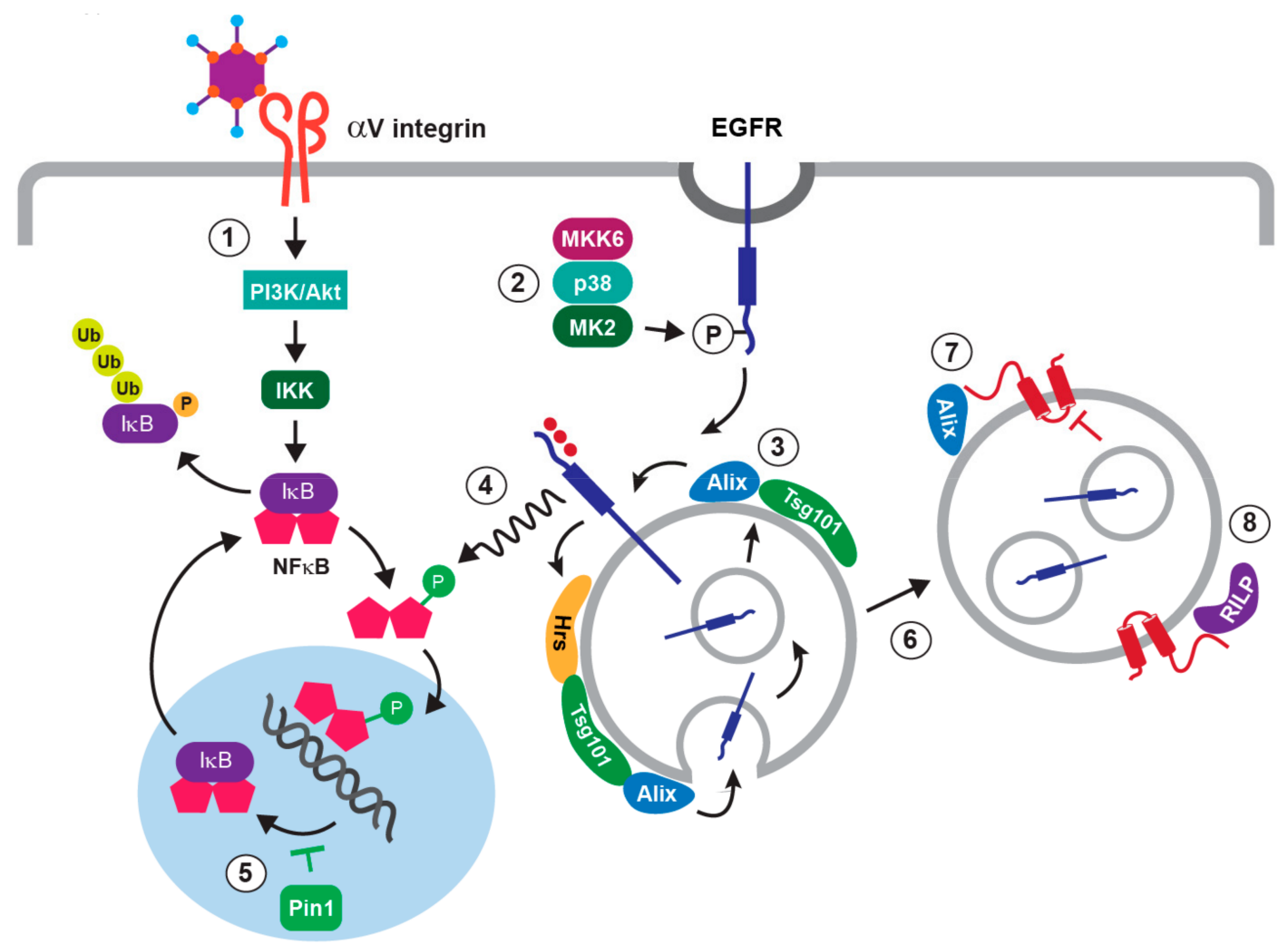

Figure 2. Hypothetical model for adenoviral regulation of stress-induced EGFR signaling through NFKB. We hypothesize that viral cell entry activates two host cell pathways converging on NFKB. Capsid binding to $\alpha \mathrm{V}$ integrins induces PI3K/Akt, which activates a canonical NFKB signaling pathway by promoting degradation of inhibitory IKB proteins and also unmasks a Pin1 substrate in NFkB-p65 (1); and viral cell entry elicits clathrin-mediated EGFR uptake to a stable subset of non-degradative MVBs (multivesicular body endosomes) downstream of p38-MAPK signaling (2). Similar to other cellular stresses, we hypothesize that EGFRs cycle between ILVs and limiting membranes under regulation of ESCRT proteins Hrs, Tsg101, and Alix (3). We have shown that stress-activated EGFRs (EGF receptors) (red highlights) facilitate phosphorylation of the Pin1 NFkB-p65 substrate prior to its nuclear translocation (4), which is known to subsequently block nuclear export of IKB/NFkB complexes (5). E3-RID $\alpha$ is produced 3 to 4 hours post-infection (6). Our published data support a working model that E3-RID $\alpha$ antagonizes EGFR stress signaling from MVB limiting membranes (7); and promotes lysosomal degradation (8), by mechanisms involving host cell proteins Alix and Rab-interacting lysosomal protein (RILP).

\section{The NFKB Pathway in Adenovirus-Directed Innate Immunity}

$\mathrm{NF \kappa B}$ is a key component of the initial innate immune with important roles in severe manifestations of acute adenovirus infections and toxicity elicited by adenovirus gene therapy vectors $[12,13]$. For instance, several lines of evidence suggest that early tissue injury associated with infectious adenoviruses and adenovirus vectors is largely due to NFKB-mediated neutrophil recruitment. It has been known for nearly three decades that infectious adenoviruses can specifically induce host cell secretion of chemokine IL-8, which attracts neutrophils to sites of infection, in animal models [43,74]. More recently, studies have shown that proinflammatory cytokines including IL-8 were strongly induced in children with symptomatic human adenovirus viremia after stem cell transplantation [75]. Adenovirus has also been investigated in the pathogenesis of COPD (chronic obstructive disease), where E1A expression has been potentially linked to increased NFKB activity and IL-8 expression in response to inflammatory stimuli [76]. In addition, intravenously administered adenoviral vectors significantly increased chemokine production, which correlated with acute neutrophil-mediated hepatic injury, in human adenovirus vector-exposed mice [77]. 
The NFKB family is comprised of multiple subunits (RelA/p65, c-Rel, RelB, p50 and p52), which assemble combinatorially into functioning homo- and heterodimers capable of dimer-specific gene activation [78]. NFKB subunits are sequestered in the cytoplasm as inactive dimers bound to inhibitory IкB proteins in resting cells (Figure 2) [79]. Most upstream stimuli activate NFkB by inducing phosphorylation-dependent proteasomal degradation of IKB proteins [79]. This activation step is primarily regulated by inducible IKKs, which are composed of a heterodimer of the catalytic IKK $\alpha$ and IKK $\beta$ subunits, and a regulatory protein called NEMO (NFKB essential modulator) or IKK $\gamma$ [80]. Two IKK-related kinases have also been identified (TBK1 and IKKE). Primarily known for activating the transcription factors IRF3 and IRF7, which are critical for expression of type I interferon genes, TBK1 and IKK $\varepsilon$ are both reported to be NFKB-activating kinases [81]. The serine/threonine-specific protein kinase Akt also regulates NFKB by binding and activating IKK $\alpha$ [82]. Liberated NFKB dimers then translocate to the nucleus, where they bind specific DNA sequences via a conserved Rel homology domain (RHD) at their N-terminus.

One important mechanism for terminating NFKB responses involves de novo synthesized IKB proteins, which enter the nucleus, remove NFKB from DNA, and relocalize it to the cytosol where it is subsequently targeted for proteasomal degradation (Figure 2) [83]. It is also known that nuclear NFkB function is regulated by Pin1, a peptidyl-prolyl isomerase which controls protein function by catalyzing conformational changes at specific pSer/Thr-Pro motifs, which are substrates for proline-directed kinases such as ERK-MAPK [84]. Studies have revealed that cytokine treatment induces phosphorylation at the Thr254-Pro motif in the NFKB p65 subunit, leading to Pin1 binding following nuclear translocation, prolyl isomerization, inhibition of $\mathrm{p} 65$ binding to $\operatorname{I} \mathrm{B} \alpha$, and increased nuclear stability and activity of NFKB $[85,86]$. Deregulated Pin1 function has been implicated in various diseases, and Pin1 is being investigated as a potential therapeutic target in cancer and immune disorders [87-89]. Pin1 is also emerging as an important factor in viral pathogenesis. For instance, Pin1 has been reported to limit RNA virus-dependent tissue damage caused by type I interferons, by inducing proteasomal destruction of IRF3 transcription factor [90]. Recent studies have also revealed that Pin1 regulates stability and function of several virally-encoded phosphoproteins, including hepatitis B virus $\mathrm{X}$ protein, HTLV-1 Tax protein, and HIV integrase [91].

The NFKB signaling pathway promotes inflammation and immunity against pathogens by regulating the expression of an array of pro-inflammatory mediators, including cytokines and chemokines [79]. The NFKB-driven innate immune response to infectious adenovirus has been examined extensively in macrophages and epithelial cells, which are the first two cell types to engage adenovirus during an acute respiratory tract infection. Although alveolar macrophages are generally non-permissive for viral replication, several lines of evidence suggest that they elicit innate immune responses following adenovirus internalization. For instance, blood macrophages have been shown to produce inflammatory cytokines following exposure to adenovirus in vitro; and internalization of adenovirus by alveolar macrophages initiates early proinflammatory signaling during acute respiratory tract infection in vivo [92-94]. It has also been shown that the infectious adenovirus life cycle activates inflammatory signaling pathways in epithelial cells both in vitro and in vivo [44]. In vitro co-culture studies have revealed that the innate immune response to adenovirus is significantly enhanced through a synergistic interaction between macrophages and epithelial cells, by a mechanism requiring $\mathrm{NF} \kappa \mathrm{B}$ activity, as well as direct physical contact between these two cell types [95]. There is also evidence that basal and induced NFKB activity protects epithelial cells from the inflammation they induce by activating local innate immune responses [65].

\section{Stress-Induced EGFR Responses}

EGFR is activated by ligand binding at the cell surface, resulting in autophosphorylation on specific tyrosine residues within the cytoplasmic tail that serve as docking sites for a range of proteins regulating multiple intracellular signaling pathways [96]. Ligand-activated EGFRs are rapidly internalized to endosomes that enable signaling from unique intracellular platforms $[97,98]$. Endocytosis also 
instigates the process of signal termination since receptors are targeted for degradation by the ESCRT (endosomal sorting complexes required for transport) machinery, which recognizes ubiquitin moieties attached to EGFR at plasma membrane [99,100]. Briefly, ESCRT-0 comprised of Hrs and Stam1 subunits sequesters cargo in peripheral early endosomes, and ESCRT-I and ESCRT-II act sequentially to sort cargo into inward invaginations of limiting membranes of MVB (multivesicular body) endosomes [101]. ESCRT-III then facilitates cargo deubiquitination and membrane scission finalizing formation of ILVs (intraluminal vesicles), which are subsequently hydrolyzed in lysosomes following late endosome/MVB-lysosome fusion [102].

Recent studies have shown that a variety of cellular stresses, or stress inducers such as TNF- $\alpha$, stimulate a robust, non-canonical pathway of ligand-independent EGFR trafficking, downstream of a p38-MAPK/MK2 signaling cascade (Figure 2) [103-105]. In contrast to ligand-stimulated EGFRs that are targeted for degradation, stress-internalized EGFRs arrest in a relatively stable population of MVB endosomes, where they are subsequently activated in the absence of ligand $[103,104]$. The stress-internalized EGFRs localize to ILVs capable of undergoing dynamic cycles of fission and fusion at the MVB limiting membrane, which is thought to facilitate EGFR stress signaling via cytosolic substrates [106]; and EGFR recycling back to plasma membrane when p38-MAPK activity declines [107]. Stress-induced EGFR sorting has been shown to be regulated by a subset of ESCRT proteins comprising Hrs and Tsg101, which are subunits of ESCRT-0 and ESCRT-I respectively, and the ESCRT accessory protein Alix [106]. The requirements for Alix and Hrs were not surprising, since both of these ESCRT-associated proteins had already been linked to non-conventional endosomal sorting: Alix by mediating ubiquitin-independent MVB sorting of P2Y $\mathrm{Y}_{1}$ purinergic receptors; and Hrs through recognition of hydrophobic amino acid clusters regulating degradation of cytokine receptors [108,109]. Although its role remains unclear, Tsg101 reportedly controls endosome-to-cytosol release of enveloped viral RNA through an interaction with Alix, implicating a potential role in ILV back-fusion [110].

A number of EGFR signaling pathways have been linked to NFKB activation downstream of ligand stimulation or constitutive EGFR activation in cancer cells, primarily by promoting degradation of IKB proteins that sequester inactive NFKB proteins in the cytoplasm $[79,111]$. However, our recent studies provide the first evidence that stress-induced EGFR signaling contributes to the innate immune response to adenovirus by interfering with negative feedback control of NFKB activity in the nucleus (Figure 2). We found that viral cell entry induced EGFR phosphorylation at the p38-MAPK/MK2 substrate Ser1046/1047, which was previously linked to clathrin-mediated uptake of stress-exposed EGFRs [73,112]. We also found that adenovirus-induced EGFR trafficking occurred in the absence of EGFR ligand, as well as EGFR ubiquitination and intrinsic tyrosine kinase activity that are both required in the ligand-regulated trafficking pathway [113-115]. Nevertheless, EGFRs were subsequently activated, and NFKB-p65 was phosphorylated at a Thr254-Pro motif, which is a known substrate for Pin1, by a mechanism that was attributable to intrinsic EGFR kinase activity [73]. Although the EGFR-stimulated pathway regulating phosphorylation of the Thr254-Pro motif in NFkB-p65 is not currently known, the Gab1 signaling adaptor is a strong candidate. In addition to requiring trafficking to endosomes for full activation, Gab1 is known to sustain EGFR/ERK-MAPK signaling by facilitating activation of the tyrosine phosphatase Shp2 [85,86,116-118]. There is increasing evidence that many viruses exploit EGFR function to facilitate their replication, and antagonize host antiviral responses [119]. Until recently, it was generally assumed that viruses co-opted mechanisms induced by ligand-receptor interactions. However, it is well-established that viral infections can impose cellular stress and minimize or co-opt adaptive host responses [120]. Recognition that adenovirus contributed to NFKB signaling by activating a novel stress-induced EGFR pathway is significant, because unique host proteins regulating this pathway represent novel drug targets for therapeutic development.

\section{Innate Immunity and Early Adenoviral-Induced Gene Products}

Adenoviral proteins encoded by early region genes elicit a second wave of NFkB activity 3 to $4 \mathrm{~h}$ post-infection. Respiratory epithelial cells are normally unresponsive to bacterially-derived LPS 
(lipopolysaccharides), which is present as a contaminant on airborne particles and activates NFKB following its binding to TLR4 (Toll-like receptor 4) [121]. However, multiple lines of evidence indicate that the adenoviral E1A (early region 1A) protein sensitizes infected respiratory epithelial cells to LPS/TLR4/NFKB signaling. First, some investigators have suggested a role for persistent E1A expression in COPD [122]. Second, primary human bronchial epithelial cells that stably expressed the adenovirus E1A protein displayed enhanced pro-inflammatory NFKB signaling, compared to untransfected control cells [123]. Finally, enhanced susceptibility to LPS and other microbial inducers of inflammation have been implicated in the acute inflammatory responses to adenovirus infections and toxicity of adenovirus vectors used in gene therapy $[124,125]$. A second early viral gene product with known involvement in NFKB signaling is the $19 \mathrm{~K}$ protein encoded by the E3 region (E3-19K). E3-19K is a membrane protein that binds and retains MHC class I molecules in the ER, suppressing anti-adenovirus activities of T cells [1,126-128]. This interaction subsequently triggers ER protein overload, leading to calcium release, production of reactive oxygen intermediates, and NFKB activation [129]. In addition to early viral gene products, NFKB activity is also regulated by TNF- $\alpha$ released from adenovirus-stimulated alveolar macrophages, and recognized by TNFR1 (Tumor necrosis factor receptor 1) located on the apical surface of respiratory epithelial cells (Figure 1d) $[93,130]$. In addition to the TNFR1 adaptor molecule TRADD, which assembles a multi-adaptor complex inducing I $k B$ degradation, we have shown that TNF- $\alpha$ controls nuclear NFKB stability through the stress-activated EGFR signaling pathway described in adenovirus-infected cells $[73,131]$. In contrast to virally-induced events that have a positive role in NFKB signaling, the E3-14.7 adenoviral protein inhibits NFKB gene transcription occurring downstream of both LPS and TNF- $\alpha$, through a direct interaction with the NFKB p50 subunit that inhibits DNA binding [132]. The NEMO/IKK $\gamma$ regulatory subunit of the IKK complex has also been reported to be an E3-14.7 binding partner [133]. However, this physiological relevance of this interaction remains unknown, since it had no effect on NEMO/IKK $\gamma$ function [133]. Adenovirus also encodes two viral-associated RNAs (VA-I and VA-II), that are synthesized during the early phase through the late phase of infection [134]. Recent studies have revealed that these non-coding RNAs induce the production of type I interferons, but not inflammatory cytokines [135].

\section{Innate Immunity and the E3-RID $\alpha$ Protein}

We have characterized three independent roles for the E3 gene product E3-RID $\alpha$ encoded by group $\mathrm{C}$ adenoviruses (HAdV-C2 and HAdV-C5) in modulating NFKB activity in cultured respiratory epithelial cells (Figure 1d). E3-RID $\alpha$ is a type II transmembrane protein localized to early endosomes, where it regulates sorting of both membrane protein and lipid cargoes [114,136-138]. Our studies have identified several small modules composed of 2-6 residues located in the cytosolic E3-RID $\alpha$ C-terminal region, regulating functional interactions with the following host proteins or protein complexes (Figure 3): (i) The clathrin adaptor AP1, which assists in the temporal regulation of the viral protein by facilitating its localization to endosomes [139]; (ii) the ESCRT accessory protein Alix involved in EGFR trafficking induced by cell stress, including adenoviral infection [73]; (iii) the Rab7 effector Rab-interacting lysosomal protein (RILP), which controls late endosome transport and positioning, and late endosome-lysosome fusion [140,141]; and (iv) a second Rab7 effector called ORP1L (Oxysterol-Binding Protein-Related Protein 1L), which supports many RILP functions, and also contributes to lipid trafficking at membrane contacts between late endosomes and ER [138,142,143]. We have shown that the C-terminal tail of the viral protein is intrinsically disordered, suggesting E3-RID $\alpha$ function is regulated by disorder-to-order transitions induced by binding to its various protein partners [144]. The dynamic nature of these interactions is also supported by the finding that E3-RID $\alpha$ function relies on the reversible attachment of palmitic acid to Cys67 in its cytosolic tail (Figure 3) [145]. Although the role of this modification is not currently known, it could elicit conformations that are favorable for binding host cell proteins, or regulate E3-RID $\alpha$ targeting to endosomal lipid rafts [146]. 


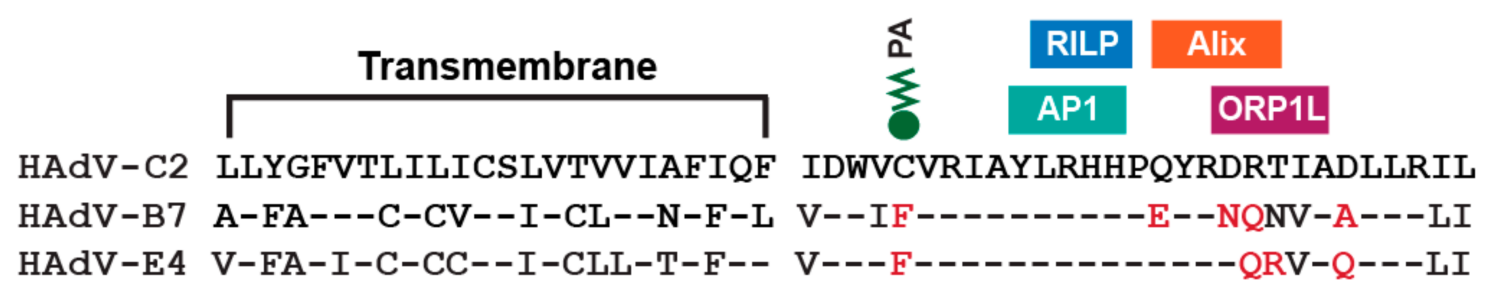

Figure 3. Sequence alignment of published RID- $\alpha$ transmembrane and cytosolic tail sequences from adenovirus serotypes HAdV-C2, HAdV-B7, and HAdV-D4. HAdV-C2 RID $\alpha$ is known to interact with multiple cellular proteins described in the text, and is also reversibly modified with palmitic acid (PA) at Cys67. Divergent amino acids affecting the Cys67 palmitoylation site, or introducing negative/positive to uncharged amino acid substitutions, are highlighted in red.

The first mechanism involves the ability of E3-RID $\alpha$ to attenuate the stress-induced EGFR signaling pathway that antagonizes negative feedback control of nuclear NFKB activity in respiratory epithelial cells (Figure 2) [73]. Our published results indicated that EGFRs were diverted away from the Tsg101-dependent trafficking step in the stress-induced MVB sorting pathway, following the onset of early viral gene expression [73]. Phosphorylation at the Thr254-Pro Pin1 substrate in the p65 subunit of

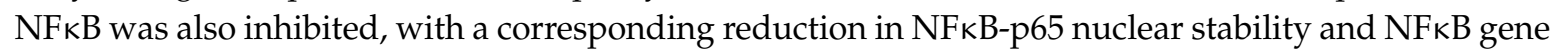
transcription [73]. In addition, E3-RID $\alpha$ expression was associated with down-regulated EGFR/NFKB signaling induced by TNF- $\alpha$ in the absence of other viral proteins, supporting a role for E3-RID $\alpha$ in infected cells [73]. These findings also suggested that ILV back-fusion required for EGFR signaling from MVB limiting membranes was somehow blocked. Our finding that E3-RID $\alpha$ formed a physical complex with the ESCRT accessory protein Alix support a working model that the viral protein could interfere with a back-fusion process regulated by an interaction between Alix and Tsg101, as has been suggested for endosome-to-cytosol release of enveloped viral RNA [110]. It was already known that Pin1 modulates NFKB signaling following its release from $\operatorname{I\kappa B} \alpha$, which exposes the Thr254-Pro motif in the p65 subunit, in cytokine-treated cells [86]. Similarly, EGFR-dependent phosphorylation of the NFkB-p65 Thr254-Pro motif in infected cells probably requires I $k B \alpha$ degradation downstream of PI3K/Akt signaling, which is probably induced by PI3K/Akt signaling downstream of capsid binding to $\alpha \mathrm{V}$ integrins [67]. It seems unlikely that E3-RID $\alpha$-mediated reduction of stress-induced EGFR signaling would have much of an effect on this first wave of NFKB activity downstream of viral cell entry, if cells are infected at relatively low multiplicity of infection (MOI). However, Pin1-deficient mice and cells are refractory to NFKB activation by cytokine signals, suggesting that E3-RID $\alpha$ could have a significant impact on NFKB activity induced by exposure to TNF- $\alpha$ released by adenovirus-activated macrophages [86]. On the other hand, failure to down-regulate EGFR stress signaling could lead to constitutive NFKB activity, by blocking its nuclear export in the absence of external stimuli.

A second mechanism for regulating NFKB signaling involves the interaction between E3-RID $\alpha$ and the Rab7 effector molecule RILP [147]. In some of our earlier studies, we noted that infection with a mutant virus lacking E3-RID $\alpha$ expression had a gross morphological effect on the endolysosomal network [145]. The aberrant phenotype was characterized by cholesterol accumulation in dysmorphic perinuclear compartments enriched for early and late endosomal markers [145]. By comparison, endolysosomal compartments were largely devoid of free cholesterol, and were similarly distributed in the cytoplasm, in mock-treated and HAdV-C2-infected cells [145]. We had also previously established that E3-RID $\alpha$ expression was required to divert internalized EGFRs from a recycling to a lysosomal degradative pathway in infected cells $[113,114]$. However, adenovirus-induced EGFR degradation was not impaired by reduced function of the small GTPase Rab7, which is critically important for late endosome/lysosome function $[73,148]$. Interestingly, we had isolated RILP, which couples Rab7-positive vesicles to the HOPS (homotypic fusion and vacuole protein sorting) tethering complex required for late endosome-lysosome fusion, in a yeast two-hybrid screen for E3-RID $\alpha$ binding partners [147]. To determine whether the interaction between E3-RID $\alpha$ and RILP 
activated an alternative degradative pathway, cells were transfected with a plasmid encoding a dominant-inhibitory RILP fragment, which blocks the interaction between RILP and HOPS without affecting RILP binding to E3-RID $\alpha[140,147]$. We found that this fragment led to a significant reduction in EGFR degradation associated with E3-RID $\alpha$ expression by infectious virus [147]. In addition, the wild-type E3-RID $\alpha$ protein, but not a mutant protein defective for RILP binding, was sufficient to reconstitute lysosomal degradation of LDL (low density lipoprotein) following its receptor-mediated uptake in Rab7-depleted cells [147]. E3-RID $\alpha$ expression also reconstituted ligand-induced EGFR degradation in cells with reduced Rab7 function [73]. Altogether, these results support a working model that the interaction between E3-RID $\alpha$ and RILP facilitates a lysosome sorting mechanism normally regulated by Rab7, which was disabled by adenovirus infection. Although the mechanism of Rab7 inactivation is not currently known, it probably occurs downstream of one of the myriad pathways that are activated by viral cell entry. For instance, Rab7 is emerging as a target for signaling pathways that disrupt its interaction with RILP through Rab7 phosphorylation [149].

Impaired Rab7 function would be beneficial for viral replication, by preventing adenovirus clearance in lysosomes. However, the reported ability of infected cells to evade premature death from TNF- $\alpha$-induced apoptosis by down-regulating TNFR1 requires a functional endolysosomal system [150]. Adenovirus-induced TNFR1 down-regulation is known to be regulated by a functional interaction between E3-RID $\alpha$ and a second E3 protein called E3-14.5 (or RID $\beta$ ) [150-152]. We hypothesize that TNFR1 down-regulation occurs in a two-step process. The first step involves clathrin-mediated TNFR1 internalization, possibly through an interaction between E3-14.5 and AP2 clathrin adaptors [151]. Our data suggest that E3-RID $\alpha$ directs the second step in this virally-induced pathway, by promoting RILP-dependent late endosome-lysosome fusion in the absence of functional Rab7. In contrast to adenovirus-induced TNFR1 trafficking, E3-RID $\alpha$ is the only viral protein required for EGFR down-regulation in infected cells, because clathrin-mediated EGFR internalization is regulated by a stress-induced physiological pathway [73,153]. Similarly, E3-RID $\alpha$ expression supported EGFR degradation in Rab7-depleted cells in the absence of other viral proteins, following ligand-stimulated EGFR internalization from clathrin-coated pits [73].

The third mechanism involves the interaction between E3-RID $\alpha$ and ORP1L, a lipid binding protein belonging to the family of oxysterol-binding protein related-proteins (ORPs) [154-158]. In addition to its evolutionarily conserved lipid binding ORD (OSBP-related domain), ORP1L has amino-terminal ankyrin repeats mediating its interaction with GTP-Rab7, a pleckstrin homology (PH) domain partially responsible for targeting to late endosomes, and an FFAT [two phenylalanines (FF) in an Acidic Tract] motif (Figure 4) $[159,160]$. The ORP1L-ORD has been shown to exist in two conformations in partnership with GTP-Rab7-GTP: A membrane-bound state when late endosomal cholesterol levels are high; and a cytosolic, membrane-free conformation enabling formation of late-endosome-ER membrane contact sites via an interaction between ORP1L-FFAT and VAP (VAMP [vesicle-associated membrane protein]-associated ER protein) located in the ER [160]. In contrast, we have shown that E3-RID $\alpha$ stabilized the interaction between ORP1L and the VAP isoform VAPA under endosomal cholesterol-loading conditions that normally inhibit ORP1L/VAPA complex formation [138]. In addition, these E3-RID $\alpha$-induced membrane contact sites supported the non-vesicular flow of endosomal cholesterol down a concentration gradient to the ER, where it was rapidly converted to cholesteryl esters for storage in cytoplasmic lipid droplets by the enzyme Acyl-coenzyme A: cholesterol acyltransferase (ACAT) (Figure 4) [138]. We discovered the RID $\alpha$-dependent cholesterol transport pathway by expressing the viral protein in human fibroblasts from a patient with NPC (Niemann-Pick type C disease) bearing mutations in the NPC1 protein [145]. NPC1 is known to regulate the predominant late endosome-ER cholesterol transport pathway, and the main phenotype in cells from NPC patients is the accumulation of cholesterol and other lipids in the endosomal/lysosomal compartment [161]. We found that the interaction between E3-RID $\alpha$ and ORPIL corrected this aberrant cellular phenotype in the absence of other viral proteins, by a mechanism requiring the Cys63 palmitoylation site in the E3-RID $\alpha$ cytosolic tail [145]. It had been reported previously that NPC1 deficiency was associated 
with constitutive inflammatory signaling through TLR4 [162]. Studies had revealed that TLR4 is localized at both the cell surface and in endosomes, and that endosomal TLR4 recruits specific signaling adaptors (TRAM and TRIF) linking it to IRF3 and NFKB transcription factors [163,164]. It was also known that TLR4 associates with lipid rafts, and that its activity was modulated by levels of cellular cholesterol $[165,166]$. These properties of TLR4 may underlie its constitutive activity in NPC1-deficient cells, because NPC1-mediated cholesterol transport is required to deplete raft components from late endocytic membranes [162,167]. Since infected cells developed an NPC-like cholesterol storage phenotype following infection with an E3-RID $\alpha$-null virus, we hypothesized that the interaction between E3-RID $\alpha$ and ORP1L reconstituted homeostatic control of TLR4 signaling in endosomes [145]. Consistent with this hypothesis, LPS induced an acute transitory NFKB response in respiratory epithelial cells infected with wild-type virus $[143,145]$. In contrast, mutant viruses lacking E3-RID $\alpha$, or encoding a palmitoylation-defective E3-RID $\alpha$ protein, were both associated with sustained NFKB activity $[143,145]$. Prior to our studies, ORP1L was known to be involved in cholesterol sensing, but had not been linked to cholesterol transport [160]. However, recent studies have identified a physiological pathway for cholesterol transport regulated by the interaction between ORP1L and VAPA [142]. Our recent results suggest this physiological pathway may also have a key role in homeostatic TLR4/NFKB signaling.

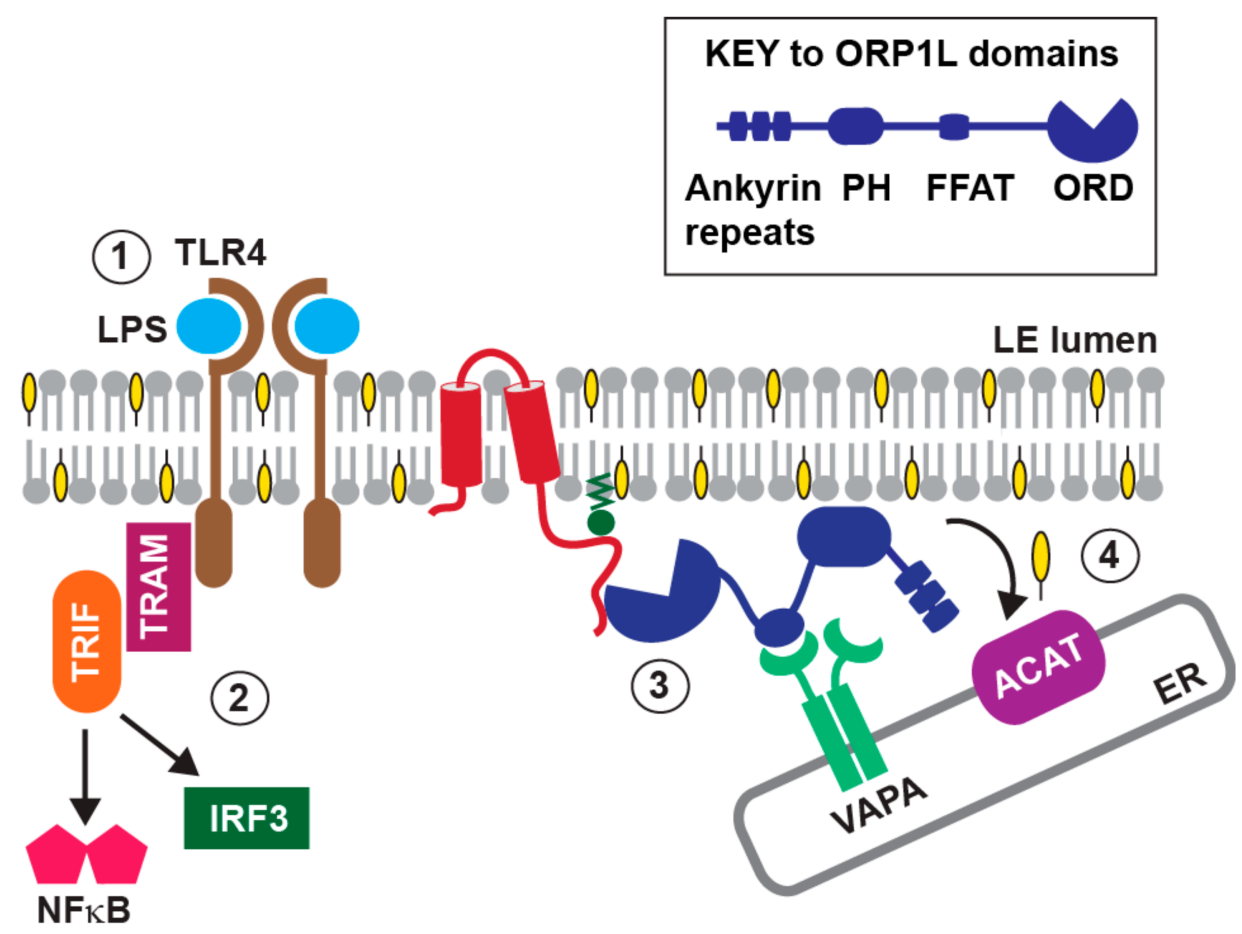

Figure 4. Hypothetical model for adenoviral regulation of cholesterol-dependent TLR4 signaling. It is already established that LPS-activated TLR4 traffics to endosomes, where it is associated with cholesterol (yellow)-enriched lipid rafts (1); and that endosomal TLR4 regulates NFKB and IRF3 signaling by engaging TRAM/TRIF adaptors (2). Our studies support a working model that E3-RID $\alpha$ promotes formation of ORP1L-VAP membrane contacts (3), which regulate cholesterol-dependent TLR4 signaling through cholesterol transport to ER for esterification by Acyl-coenzyme A: cholesterol acyltransferase (ACAT) (4).

\section{Conclusions and Future Perspectives}

To perform its important role in epithelial cells, NFkB activity must be tightly regulated to ensure that: (1) its cytoprotective functions are preserved; (2) pro-inflammatory responses are rapidly induced by pathogen challenge; and (3) the initial pro-inflammatory response is down-regulated to prevent excessive tissue damage and injury [65]. Many human pathogens have evolved strategies 
to modulate NFKB activity by targeting mechanisms regulating $\mathrm{I} \kappa \mathrm{B} \alpha$ degradation downstream of inducible IKKs or IKK-like kinases [168]. Our recent studies indicate that the E3-RID $\alpha$ protein also targets the NFKB pathway, but by mechanisms that had not been previously described $[73,143]$.

Although E3-RID $\alpha$ was originally identified for its ability to down-regulate EGFR, this activity had not definitively been associated with a biological function [114]. We have now shown that E3-RID $\alpha$ antagonizes stress-induced EGFR signaling associated with enhanced NFkB stability and gene transcription. Since this stress-induced EGFR pathway occurred downstream of adenoviral cell entry, its impact on innate immunity could be related to MOI. On the one hand, low MOIs will support viral replication during a primary infection [169]. Under these conditions, the stress-induced EGFR pathway may primarily regulate $N F \kappa B$ activity that is cytoprotective. On the other hand, one viral particle can replicate up to $10^{6}$ new progeny leading to high MOI secondary infections in surrounding tissue [170]. Although these secondary infections induce cell death before the virus can replicate, they may also cause an exaggerated EGFR stress response contributing to adenoviral pathogenesis, if left unchecked by E3-RID $\alpha$ expression [171]. Our studies suggest that E3-RID $\alpha$ attenuates stress-induced EGFR signaling by orchestrating a novel two-step process. The first step appears to block ESCRT machinery regulating EGFR signaling from MVB limiting membranes. The second step then facilitates lysosomal degradation by a mechanism that may compensate for loss-of-Rab7 function induced by viral cell entry.

$\mathrm{NF} \kappa \mathrm{B}$ activity is deregulated in various inflammatory diseases, making the NFkB signaling pathway an attractive target for anti-inflammatory therapies. Several categories of inhibitors have been developed, which block different steps in the canonical NFKB activation cascade [172]. The finding that stress-activated EGFRs regulate NFKB activity via a mechanism involving a host cell Pin1 substrate could provide a foundation for more selective therapies with Pin1 inhibitors, which are currently being developed for cancer therapy [172]. Further examination of Pin1 substrates, either in viral proteins with critical roles in replication, or host cell pathways contributing to innate immunity, represents an important topic for future investigation.

In addition to its role in down-regulating a stress-induced EGFR/NFKB pathway, we have found that E3-RID $\alpha$ modulates NFKB activity downstream of the LPS receptor TLR4, through formation of membrane contact sites controlling endosomal cholesterol levels. Virus-induced membrane contact sites are emerging as key players in the formation of specialized membranous replication organelles with unique lipid composition, which facilitate robust replication of positive-strand RNA viruses [173]. However, to our knowledge, our studies are the first to link membrane contacts to innate immune signaling associated with a pathogen-induced pathway. We have also shown that E3-RID $\alpha$-stabilized ORP1L/VAP complexes appear to keep ER cholesterol concentrations low enough to alleviate negative feedback inhibition of SREBP1 (sterol regulatory element binding protein 1) transcription factor activation [143]. Since SREBP-1 regulates production of fatty acid metabolites that antagonize NFkB-dependent transcription, this may provide another means of fine-tuning NFkB responses to adenovirus infection [174].

E3-RID $\alpha$ activities could also be important factors in adenovirus disease associated with specific adenovirus strains such as HAdV-B7 and HAdV-E4, which account for several recent highly publicized outbreaks [21,175]. In contrast to $E 1 A$ and early region $1 \mathrm{~B}(E 1 B)$ genes that are conserved among different adenovirus serotypes, E3 genes vary markedly and may even be absent, supporting their potential roles in adenovirus pathogenesis [27]. For instance, adenovirus E3-19K proteins encoded by different serotypes display allele-specific interactions with class I MHC molecules, implying a link between host genetic factors and susceptibility to adenovirus disease [176,177]. E3 RID $\alpha$ proteins from different serotypes exhibit significant sequence divergence in the C-terminal region encoded by HAdV-C2, which mediates interactions with host proteins involved in membrane trafficking (Figure 3). For instance, HAdV-B7 and HAdV-E4 have negative/positive to uncharged amino acid substitutions in the putative Alix binding site, which could potentially impact the strength and duration of EGFR signaling induced by stress of viral infection or exposure to TNF- $\alpha$. They also lack the Cys67 
palmitoylation site regulating endosome-ER contact site formation, suggesting they may be associated with unregulated LPS/TLR4/NFkB signaling.

Although HAdV-C serotypes are generally associated with undiagnosed or mild symptoms, they are also clinically relevant in causing severe manifestations in immunocompromised patients, particularly in allogeneic hematopoietic stem cell transplant recipients [178-180]. Whole genome sequences were recently reported for 51 circulating clinical strains derived by recombination between different HAdV-C subtypes [181]. Those studies revealed that the majority of recombination events involved E1 and E4, implicating these early transcription regions in HAdV-C virulence [181]. In contrast the entire E3 region was highly conserved, suggesting there is strong selective pressure to maintain E3 sequences [181]. It is well established that HAdV-C DNA can persist in a latent state in lymphoid cells for many years, and a role for E3-RID $\alpha$ and E3-RID $\beta$ in preventing apoptotic cell death through TNFR1 and related death domain-containing receptors has been postulated $[182,183]$. These findings suggest that E3-RID $\alpha$ encoded by HAdV-C may support reactivation of latent virus, and subsequent systemic infections, in immunosuppressed transplant patients [184].

E3-RID $\alpha$ may also have important roles in replication-selective oncolytic adenovirus vectors. In addition to a small deletion in E1A that abolishes binding to the retinoblastoma protein, the oncolytic adenovirus vector $d 1922-947$ has a second deletion eliminating expression of E3 proteins RID $\alpha$ and RID $\beta$ [185]. It was predicted that this E3 deletion might make this virus more sensitive to the antiviral effects of TNF- $\alpha$. However, recent studies have shown that that $d 1922-947$ induces a novel form of TNF- $\alpha$-independent programmed cell death, which differs from classical apoptosis and necroptosis pathways [186]. Our studies suggest an alternative mechanism involving the interaction between HAdV-C-encoded RID $\alpha$ and ORP1L illustrated in Figure 4. Loss of homeostatic RID $\alpha$ signaling through ORP1L in cells infected with $d 1922-947$ could lead to cholesterol-induced cytotoxicity, which is known to trigger a complex network of cell death pathways [187]. In addition, cholesterol accumulation in macrophages and other immune cells may provoke inflammatory responses that could have oncolytic effects in distant non-virally infected tumors [188]. In addition to co-option of cytokine-regulated inflammatory pathways that has been a primary focus of E3 biology for nearly three decades the role of cholesterol in innate immune responses to adenovirus vectors is an important topic for future investigation.

To summarize, E3-RID $\alpha$ is a remarkably versatile adenoviral membrane protein localized to endosomes, which is capable of targeting the NFKB signaling pathway by multiple mechanisms. Different pathogens tend to converge on similar pathways, usually by deploying distinct strategies. Studying how other pathogens potentially subvert the novel host cell pathways targeted by E3-RID $\alpha$ will provide fundamental new information regarding basic molecular cell biology, and is also central to understanding infectious disease.

Funding: This research was funded by Public Health Service RO1 Grant GM081498 to C.R.C.

Acknowledgments: I am grateful to my colleagues Patricia Hoffman-Towler, Denise Crooks, Ankur Shah, Nicholas Cianciola, and Xuehuo Zeng, for their many contributions to studies from the Carlin laboratory that are described in this review.

Conflicts of Interest: The author declares no conflict of interest.

\section{References}

1. Burgert, H.; Kvist, S. An adenovirus type 2 glycoprotein blocks cell surface expression of human histocompatibility class I antigens. Cell 1985, 41, 987-997. [CrossRef]

2. Berget, S.M.; Moore, C.; Sharp, P.A. Spliced segments at the $5^{\prime}$ terminus of adenovirus 2 late mRNA. Proc. Natl. Acad. Sci. USA 1977, 74, 3171-3175. [CrossRef] [PubMed]

3. Yabe, Y.; Samper, L.; Taylor, G.; Trentin, J. Cancer induction in hamsters by human type 12 adenovirus. Effect of route of injection. Proc. Soc. Exp. Biol. Med. 1963, 113, 221-224. [CrossRef] [PubMed]

4. Chinnadurai, G. Opposing oncogenic activities of small DNA tumor virus transforming proteins. Trends Microbiol. 2011, 19, 174-183. [CrossRef] [PubMed] 
5. Flatt, J.; Butcher, S. Adenovirus flow in host cell networks. Open Biol. 2019, 9, 190012. [CrossRef]

6. Cuconati, A.; White, E. Viral homologs of BCL-2: Role of apoptosis in the regulation of virus infection. Genes Dev. 2002, 16, 2465-2478. [CrossRef]

7. Burgert, H.; Blusch, J. Immunomodulatory functions encoded by the E3 transcription unit of adenoviruses. Virus Genes 2000, 21, 13-25. [CrossRef]

8. Weitzman, M. Functions of the adenovirus E4 proteins and their impact on viral vectors. Front. Biosci. 2005, 10, 1106-1117. [CrossRef]

9. Windheim, M.; Hilgendorf, A.; Burgert, H. Immune evasion by adenovirus E3 proteins: Exploitation of intracellular trafficking pathways. Curr. Top Microbiol. Immunol. 2004, 273, 229-285.

10. Horwitz, M.S. Function of adenovirus E3 proteins and their interactions with immunoregulatory cell proteins. J. Gene Med. 2004, 6 (Suppl. 1), S172-S183. [CrossRef]

11. Cianciola, N.; Carlin, C. Human adenoviruses, cholesterol trafficking, and NF-кB signaling. J. Immunol. Sci. 2018, 2, 9-14. [PubMed]

12. Muruve, D.A. The innate immune response to adenovirus vectors. Hum. Gene Ther. 2004, 15, 1157-1166. [CrossRef] [PubMed]

13. Hendrickx, R.; Stichling, N.; Koelen, J.; Kuryk, L.; Lipiec, A.; Greber, U. Innate immunity to adenovirus. Hum. Gene Ther. 2014, 25, 265-284. [CrossRef] [PubMed]

14. Rowe, W.P.; Huebner, R.J.; Gilmore, L.K.; Parrott, R.H.; Ward, T.G. Isolation of a cytopathogenic agent from human adenoids undergoing spontaneous degeneration in tissue culture. Exp. Biol. Med. 1953, 84, 570-573. [CrossRef] [PubMed]

15. Gonzalez, G.; Yawata, N.; Aoki, K.; Kitaichi, N. Challenges in management of epidemic keratoconjunctivitis with emerging recombinant human adenoviruses. J. Clin. Virol. 2019, 112, 1-9. [CrossRef] [PubMed]

16. Huang, G.; Yao, W.; Yu, W.; Mao, L.; Sun, H.; Yao, W.; Tian, J.; Wang, L.; Bo, Z.; Zhu, Z.; et al. Outbreak of epidemic keratoconjunctivitis caused by human adenovirus type 56, China, 2012. PLoS ONE 2014, 9, e110781. [CrossRef] [PubMed]

17. Rebelo-de-Andrade, H.; Pereira, C.; Giria, M.; Prudencio, E.; Brito, M.J.; Cale, E.; Taveira, N. Outbreak of acute respiratory infection among infants in Lisbon, Portugal, caused by human adenovirus serotype 3 and a new 7/3 recombinant strain. J. Clin. Microbiol. 2019, 48, 1391-1396. [CrossRef]

18. Lynch, J.P.; Fishbein, M.; Echavarria, M. Adenovirus. Semin. Respir. Crit. Care Med. 2011, 32, $494-511$. [CrossRef]

19. Arnold, A.; MacMahon, E. Adenovirus infections. Medicine 2017, 45, 777-780. [CrossRef]

20. Potter, R.; Cantrell, J.; Mallak, C.; Gaydos, J. Adenovirus-associated deaths in US military during postvaccination period, 1999-2010. Emerg. Infect. Dis. 2012, 18, 507-509. [CrossRef]

21. Kajon, A.E.; Lamson, D.M.; Bair, C.R.; Lu, X.; Landry, M.L.; Menegus, M.; George, K.S. Adenovirus type 4 respiratory infections among civilian adults, northeastern United States, 2011-2015. Emerg. Infect. Dis. 2018, 24, 201-209. [CrossRef]

22. Kajon, A.E.; Lamson, D.M.; George, K.S. Emergence and re-emergence of respiratory adenoviruses in the United States. Curr. Opin. Virol. 2019, 34, 63-69. [CrossRef] [PubMed]

23. Berk, A. Adenoviridae. In Fields Virology, 6th ed.; Knipe, D., Howley, P., Eds.; Lippincott Williams \& Wilkins: Philadelphia, PA, USA, 2013; pp. 1704-1731.

24. Tol, M.J.; Kroes, A.C.; Schinkel, J.; Dinkelaar, W.; Claas, E.C.; der Jol-van Zijde, C.M.; Vossen, J.M. Adenovirus infection in paediatric stem cell transplant recipients: Increased risk in young children with a delayed immune recovery. Bone Marrow Transplant. 2005, 36. [CrossRef]

25. Hoffman, J.A. Adenovirus infections in solid organ transplant recipients. Curr. Opin. Organ Transplant. 2009, 14, 625-633. [CrossRef] [PubMed]

26. Chakrabarti, S.; Milligan, D.W.; Moss, P.A.H.; Mautner, V. Adenovirus infections in stem cell transplant recipients: Recent developments in understanding of pathogenesis, diagnosis and management. Leuk. Lymphoma 2004, 45, 873-885. [CrossRef] [PubMed]

27. Cook, J.; Radke, J. Mechanisms of pathogenesis of emerging adenoviruses. F1000Research 2017, 6, 90. [CrossRef] [PubMed]

28. Majorant, D.; Qiu, F.; Kalil, A.C.; Wilson, N.; Florescu, D.F. Adenovirus-A deadly disease in the solid organ transplant population: Risk factors and outcomes. Transplant. Proc. 2018, 50, 3769-3774. [CrossRef] 
29. Sandkovsky, U.; Vargas, L.; Florescu, D.F. Adenovirus: Current epidemiology and emerging approaches to prevention and treatment. Curr. Infect. Dis. Rep. 2015, 16, 1-8. [CrossRef]

30. Lugthart, G.; Oomen, M.A.; der Jol-van Zijde, C.M.; Ball, L.M.; Bresters, D.; Kollen, W.J.W.; Smiers, F.J.; Vermont, C.L.; Bredius, R.G.M.; Schilham, M.W.; et al. The effect of Cidofovir on adenovirus plasma DNA levels in stem cell transplantation recipients without T cell reconstitution. Biol. Blood Marrow Transplant. 2015, 21, 293-299. [CrossRef]

31. Ljungman, P.; Ribaud, P.; Eyrich, M.; Matthes-Martin, S.; Einsele, H.; Bleakley, M.; Machaczka, M.; Bierings, M.; Bosi, A.; Gratecos, N.; et al. Cidofovir for adenovirus infections after allogeneic hematopoietic stem cell transplantation: A survey by the Infectious Diseases Working Party of the European Group for Blood and Marrow Transplantation. Bone Marrow Transplant. 2003, 31. [CrossRef]

32. Florescu, D.F.; Keck, M.A. Development of CMX001 (Brincidofovir) for the treatment of serious diseases or conditions caused by dsDNA viruses. Expert Rev. Anti-Infect. Ther. 2014, 12, 1171-1178. [CrossRef] [PubMed]

33. Hartman, Z.C.; Appledorn, D.M.; Serra, D.; Glass, O.; Mendelson, T.B.; Clay, T.M.; Amalfitano, A. Replication-attenuated Human Adenoviral Type 4 vectors elicit capsid dependent enhanced innate immune responses that are partially dependent upon interactions with the complement system. Virology 2008, 374, 453-467. [CrossRef] [PubMed]

34. Biggs, H.M.; Lu, X.; Dettinger, L.; Sakthivel, S.; Watson, J.T.; Boktor, S.W. Adenovirus-associated influenza-like illness among college students, Pennsylvania, USA. Emerg. Inf. Dis. 2018, 24, 2117-2119. [CrossRef] [PubMed]

35. McConnell, M.J.; Imperiale, D.M.J. Biology of adenovirus and its use as a vector for gene therapy. Hum. Gene Ther. 2004, 15, 1022-1033. [CrossRef] [PubMed]

36. Ghebremedhin, B. Human adenovirus: Viral pathogen with increasing importance. Eur. J. Microbiol. Immunol. 2014, 4, 26-33. [CrossRef] [PubMed]

37. Meier, O.; Greber, U.F. Adenovirus endocytosis. J. Gene Med. 2004, 6, S152-S163. [CrossRef] [PubMed]

38. Bluscha, J.H.; Deryckereb, F.; Windheima, M.; Ruzsicsa, Z.; Arnbergc, N.; Adriand, T.; Burgerta, H.-G. The novel early region 3 protein $\mathrm{E} 3 / 49 \mathrm{~K}$ is specifically expressed by adenoviruses of subgenus D: Implications for epidemic keratoconjunctivitis and adenovirus evolution. Virology 2002, 296, 94-106. [CrossRef]

39. Windheim, M.; Southcombe, J.H.; Kremmer, E.; Chaplin, L.; Urlaub, D.; Falk, C.S.; Claus, M.; Mihm, J.; Braithwaite, M.; Dennehy, K.; et al. A unique secreted adenovirus E3 protein binds to the leukocyte common antigen CD45 and modulates leukocyte functions. Proc. Natl. Acad. Sci. USA 2013, 110, E4884-E4893. [CrossRef]

40. Jiang, H.; White, E.J.; Rios-Vicil, C.I.; Xu, J.; Gomez-Manzano, C.; Fueyo, J. Human adenovirus type 5 induces cell lysis through autophagy and autophagy-triggered caspase activity. J. Virol. 2011, 85, 4720-4729. [CrossRef]

41. Crystal, R.G. Adenovirus: The first effective in vivo gene delivery vector. Hum. Gene Ther. 2014, 25 , 3-11. [CrossRef]

42. Lee, C.S.; Bishop, E.S.; Zhang, R.; Yu, X.; Farina, E.M.; Yan, S.; Zhao, C.; Zeng, Z.; Shu, Y.; Wu, X.; et al. Adenovirus-mediated gene delivery: Potential applications for gene and cell-based therapies in the new era of personalized medicine. Genes Dis. 2017, 4, 43-63. [CrossRef] [PubMed]

43. Ginsberg, H.S.; Lundholm-Beauchamp, U.; Horswoord, R.L.; Pernis, B.; Wold, W.S.M.; Chanock, R.M.; Prince, G.A. Role of early region 3 (E3) in pathogenesis of adenovirus disease. Proc. Natl. Acad. Sci. USA 1989, 86, 3823-3827. [CrossRef] [PubMed]

44. Liu, Q.; Muruve, D.A. Molecular basis of the inflammatory response to adenovirus vectors. Gene Ther. 2003, 10, 935-950. [CrossRef] [PubMed]

45. Bergelson, J.M.; Cunningham, J.A.; Droguett, G.; Kurt-Jones, E.A.; Krithivas, A.; Hong, J.S.; Horwitz, M.S.; Crowell, R.L.; Finberg, R.W. Isolation of a common receptor for coxsackie B viruses and adenoviruses 2 and 5. Science 1997, 275, 1320-1323. [CrossRef] [PubMed]

46. Gaggar, A.; Shayakhmetov, D.M.; Lieber, A. CD46 is a cellular receptor for group B adenoviruses. Nat. Med. 2003, 9, 1408-1412. [CrossRef]

47. Lenman, A.; Liaci, A.M.; Liu, Y.; Ardahl, C.; Rajan, A.; Nilsson, E.; Bradford, W.; Kaeshammer, L.; Jones, M.S.; Frangsmyr, L.; et al. Human adenovirus 52 uses sialic acid-containing glycoproteins and the coxsackie and adenovirus receptor for binding to target cells. PLoS Pathog. 2015, 11, e1004657. [CrossRef] [PubMed]

48. Arnberg, N.; Pring-Akerblom, P.; Wadell, G. Adenovirus type 37 uses sialic acid as a cellular receptor on Chang C cells. J. Virol. 2002, 76, 8834-8841. [CrossRef] 
49. Wickham, T.J.; Mathias, P.; Cheresh, D.A.; Nemerow, G.R. Integrins $\alpha_{\mathrm{v}} \beta_{3}$ and $\alpha_{\mathrm{v}} \beta_{5}$ promote adenovirus internalization but not virus attachment. Cell 1993, 73, 309-319. [CrossRef]

50. Nemerow, G. Cell receptors involved in adenovirus entry. Virology 2000, 274, 1-4. [CrossRef]

51. Ashbourne, E.K.J.D.; Moninger, T.; Zabner, J. The Coxsackie B Virus and Adenovirus receptor resides in a distinct membrane microdomain. J. Virol. 2003, 77, 2559-2567. [CrossRef]

52. Kotha, P.L.N.; Sharma, P.; Kolawole, A.O.; Yan, R.; Alghamri, M.S.; Brockman, T.L.; Gomez-Cambronero, J.; Excoffon, K.J.D.A. Adenovirus entry from the apical surface of polarized epithelia is facilitated by the host innate immune response. PLoS Pathog. 2015, 11, e1004696. [CrossRef] [PubMed]

53. Lütschg, V.; Boucke, K.; Hemmi, S.; Greber, U. Chemotactic antiviral cytokines promote infectious apical entry of human adenovirus into polarized epithelial cells. Nat. Commun. 2011, 2, 391-394. [CrossRef] [PubMed]

54. Maier, O.; Marvin, S.A.; Wodrich, H.; Campbell, E.M.; Wiethoff, C.M. Spatiotemporal dynamics of adenovirus membrane rupture and endosomal escape. J. Virol. 2012, 86, 10821-10828. [CrossRef] [PubMed]

55. Gastaldelli, M.; Imelli, N.; Boucke, K.; Amstutz, B.; Meier, O.; Greber, U.F. Infectious adenovirus type 2 transport through early but not late endosomes. Traffic 2008, 9, 2265-2278. [CrossRef] [PubMed]

56. Wiethoff, C.M.; Wodrich, H.; Gerace, L.; Nemerow, G.R. Adenovirus protein VI mediates membrane disruption following capsid disassembly. J. Virol. 2005, 79, 1992-2000. [CrossRef] [PubMed]

57. Andrews, N.W.; Almeida, P.E.; Corrotte, M. Damage control: Cellular mechanisms of plasma membrane repair. Trends Cell Biol. 2014, 24, 734-742. [CrossRef]

58. Luisoni, S.; Suomalainen, M.; Boucke, K.; Tanner Lukas, B.; Wenk Markus, R.; Guan Xue, L.; Grzybek, M.; Coskun, A.; Greber, U.F. Co-option of membrane wounding enables virus penetration into cells. Cell Host Microbe 2016, 18, 75-85. [CrossRef] [PubMed]

59. Burckhardt, C.J.; Suomalainen, M.; Schoenenberger, P.; Boucke, K.; Hemmi, S.; Greber, U.F. Drifting motions of the adenovirus receptor CAR and immobile integrins initiate virus uncoating and membrane lytic protein exposure. Cell Host Microbe 2011, 10, 105-117. [CrossRef]

60. Ryter, S.W.; Choi, A.M.K. Autophagy in the lung. Proc. Am. Thorac. Soc. 2010, 7, 13-21. [CrossRef]

61. Zeng, X.; Carlin, C.R. Host cell autophagy modulates early stages of adenovirus infections in airway epithelial cells. J. Virol. 2013, 87, 2307-2319. [CrossRef]

62. Kreibich, S.; Emmenlauer, M.; Fredlund, J.; Ramo, P.; Munz, C.; Dehio, C.; Enninga, J.; Hardt, W.-D. Autophagy proteins promote repair of endosomal membranes damaged by the Salmonella type three secretion system 1. Cell Host Microbe 2015, 18, 527-537. [CrossRef] [PubMed]

63. DeSelm, C.J.; Miller, B.C.; Zou, W.; Beatty, W.L.; van Meel, E.; Takahata, Y.; Klumperman, J.; Tooze, S.A.; Teitelbaum, S.L.; Virgin, H.W. Autophagy proteins regulate the secretory component of osteoclastic bone resorption. Dev. Cell 2011, 21, 966-974. [CrossRef] [PubMed]

64. Miyazawa, N.; Crystal, R.G.; Leopold, P.L. Adenovirus serotype 7 retention in a late endosomal compartment prior to cytosol escape is modulated by fiber protein. J. Virol. 2001, 75, 1387-1400. [CrossRef] [PubMed]

65. Pasparakis, M. Regulation of tissue homeostasis by NF- $\mathrm{B}$ signalling: Implications for inflammatory diseases. Nat. Rev. Immunol. 2009, 9, 778-788. [CrossRef] [PubMed]

66. Tamanini, A.; Nicolis, E.; Bonizzato, A.; Bezzerri, V.; Melotti, P.; Assael, B.M.; Cabrini, G. Interaction of adenovirus type 5 fiber with the Coxsackievirus and Adenovirus Receptor activates inflammatory response in human respiratory cells. J. Virol. 2006, 80, 11241-11254. [CrossRef] [PubMed]

67. Liu, Q.; White, L.R.; Clark, S.A.; Heffner, D.J.; Winston, B.W.; Tibbles, L.A.; Muruve, D.A. Akt/protein kinase B activation by adenovirus vectors contributes to NFKB-dependent CXCL10 expression. J. Virol. 2005, 79, 14507-14515. [CrossRef] [PubMed]

68. Lam, E.; Stein, S.; Falck-Pedersen, E. Adenovirus detection by the cGAS/STING/TBK1 DNA sensing cascade. J. Virol. 2014, 88, 974-981. [CrossRef]

69. Barber, G.N. STING: Infection, inflammation and cancer. Nat. Rev. Immunol. 2015, 15, 760-770. [CrossRef]

70. Suomalainen, M.; Nakano, M.Y.; Boucke, K.; Keller, S.; Greber, U.F. Adenovirus-activated PKA and p38/MAPK pathways boost microtubule-mediated nuclear targeting of virus. EMBO J. 2001, 20, 1310-1319. [CrossRef]

71. Togo, T. Long-term potentiation of wound-induced exocytosis and plasma membrane repair is dependent on cAMP-response element-mediated transcription via a protein kinase C- and p38 MAPK-dependent pathway. J. Biol. Chem. 2004, 279, 44996-45003. [CrossRef] 
72. Tibbles, L.A.; Spurrell, J.C.L.; Bowen, G.P.; Liu, Q.; Lam, M.; Zaiss, A.K.; Robbins, S.M.; Hollenberg, M.D.; Wickham, T.J.; Muruve, D.A. Activation of p38 and ERK signaling during adenovirus vector cell entry lead to expression of the C-X-C chemokine IP-10. J. Virol. 2002, 76, 1559-1568. [CrossRef] [PubMed]

73. Zeng, X.; Carlin, C. Adenovirus early region 3 RIDa protein limits NFkB signaling through stress-activated EGF receptors. PLoS Pathog. 2019, in review.

74. Ginsberg, H.; Moldawer, L.; Sehgal, P.; Redington, M.; Kilian, P.; Chanock, R.; Prince, G. A mouse model for investigating the molecular pathogenesis of adenovirus pneumonia. Proc. Natl. Acad. Sci. USA 1991, 88, 1651-1655. [CrossRef] [PubMed]

75. Haveman, L.M.; De Jager, W.; Van Loon, A.M.; Claas, E.C.J.; Prakken, B.J.; Bierings, M. Different cytokine signatures in children with localized and invasive adenovirus infection after stem cell transplantation. Ped. Transpl. 2010, 14, 520-528. [CrossRef] [PubMed]

76. Hayashi, S.; Hogg, J.C. Adenovirus infections and lung disease. Curr. Opin. Pharmacol. 2007, 7, $237-243$. [CrossRef] [PubMed]

77. Muruve, D.A.; Barnes, M.J.; Stillman, I.E.; Libermann, T.A. Adenoviral gene therapy leads to rapid induction of multiple chemokines and acute neutrophil-dependent hepatic injury in vivo. Hum. Gene Ther. 1999, 10, 965-976. [CrossRef]

78. Wang, V.Y.-F.; Huang, W.; Asagiri, M.; Spann, N.; Hoffmann, A.; Glass, C.; Ghosh, G. The transcriptional specificity of NF-kB dimers is coded within the $\kappa B$ DNA response elements. Cell Rep. 2014, 2, 824-839. [CrossRef]

79. Napetschnig, J.; Wu, H. Molecular basis of NF-кB signaling. Annu. Rev. Biophys. 2013, 42, 443-468. [CrossRef]

80. Hacker, H.; Karin, M. Regulation and function of IKK and IKK-related kinases. Sci. STKE 2006, 2006 , re13. [CrossRef]

81. Durand, J.K.; Zhang, Q.; Baldwin, A.S. Roles for the IKK-related kinases TBK1 and IKKe in cancer. Cells 2018, 7, 139-146. [CrossRef]

82. Romashkova, J.A.; Makarov, S.S. NF-kB is a target of AKT in anti-apoptotic PDGF signalling. Nature 1999, 401, 86-90. [CrossRef] [PubMed]

83. Oeckinghaus, A.; Ghosh, S. The NF- $\mathrm{BB}$ family of transcription factors and its regulation. CSH Perspect. Biol. 2009, 1, a000034. [CrossRef]

84. Lu, K.P.; Zhou, X.Z. The prolyl isomerase PIN1: A pivotal new twist in phosphorylation signalling and disease. Nat. Rev. Mol. Cell Biol. 2007, 8, 904. [CrossRef] [PubMed]

85. Xing, D.; Gong, K.; Feng, W.; Nozell, S.E.; Chen, Y.-F.; Chatham, J.C.; Oparil, S. O-GlcNAc modification of NFkB p65 inhibits TNF-a-induced inflammatory mediator expression in rat aortic smooth muscle cells. PLOS ONE 2011, 6, e24021. [CrossRef]

86. Ryo, A.; Suizu, F.; Yoshida, Y.; Perrem, K.; Liou, Y.-C.; Wulf, G.; Rottapel, R.; Yamaoka, S.; Lu, K.P. Regulation of NF-kB signaling by Pin1-dependent prolyl isomerization and ubiquitin-mediated proteolysis of p65/RelA. Mol. Cell 2003, 12, 1413-1426. [CrossRef]

87. Butterfield, D.A.; Abdul, H.M.; Opii, W.; Newman, S.F.; Joshi, G.; Ansari, M.A.; Sultana, R. Review: Pin1 in Alzheimer's disease. J. Neurochem. 2006, 98, 1697-1706. [CrossRef] [PubMed]

88. Yeh, E.S.; Means, A.R. PIN1, the cell cycle and cancer. Nat. Rev. Cancer 2007, 7, 381-386. [CrossRef] [PubMed]

89. Nath, P.R.; Isakov, N. Insights into peptidyl-prolyl cis-trans isomerase structure and function in immunocytes. Immunol. Lett. 2015, 163, 120-131. [CrossRef]

90. Goutagny, N.; Severa, M.; Fitzgerald, K.A. Pin-ning down immune responses to RNA viruses. Nat. Immunol. 2006, 7, 555-557. [CrossRef] [PubMed]

91. Kojima, Y.; Ryo, A. Pinning down viral proteins: A new prototype for virus-host cell interaction. Front. Microbiol. 2010, 1, 107-112. [CrossRef]

92. Higginbotham, J.N.; Seth, P.; Blaese, R.M.; Ramsey, W.J. The release of inflammatory cytokines from human peripheral blood mononuclear cells in vitro following exposure to adenovirus variants and capsid. Hum. Gene Ther. 2002, 13, 129-141. [CrossRef] [PubMed]

93. Zsengellar, Z.; Otake, K.; Hossain, S.-A.; Berclaz, P.-Y.; Trapnell, B.C. Internalization of adenovirus by alveolar macrophages initiates early proinflammatory signaling during acute respiratory tract infection. J. Virol. 2000, 74, 9655-9667. [CrossRef] [PubMed] 
94. Carey, B.; Staudt, M.K.; Bonaminio, D.; van der Loo, J.C.M.; Trapnell, B.C. PU.1 redirects adenovirus to lysosomes in alveolar macrophages, uncoupling internalization from infection. J. Immunol. 2007, 178, 2440-2447. [CrossRef] [PubMed]

95. Lee, B.H.; Kushwah, R.; Wu, J.; Ng, P.; Palaniyar, N.; Grinstein, S.; Philpott, D.J.; Hu, J. Adenoviral vectors stimulate innate immune responses in macrophages through cross-talk with epithelial cells. Immunol. Lett. 2010, 134, 93-102. [CrossRef] [PubMed]

96. Schlessinger, J. Cell signaling by receptor tyrosine kinases. Cell 2000, 103, 211-225. [CrossRef]

97. Von Zastrow, M.; Sorkin, A. Signaling on the endocytic pathway. Curr. Opin. Cell Biol. 2007, 19, 436-445. [CrossRef]

98. Sorkin, A.; von Zastrow, M. Endocytosis and signalling: Intertwining molecular networks. Nat. Rev. Mol. Cell Biol. 2009, 10, 609-622. [CrossRef]

99. Raiborg, C.; Malerod, L.; Pedersen, N.M.; Stenmark, H. Differential functions of Hrs and ESCRT proteins in endocytic membrane trafficking. Exp. Cell Res. 2008, 314, 801-813. [CrossRef]

100. Hurley, J.H.; Emr, S.D. The ESCRT complexes: Structure and mechanism of a membrane-trafficking network. Annu. Rev. Biophys. Biomol. Struct. 2006, 35, 277-298. [CrossRef]

101. Wollert, T.; Hurley, J.H. Molecular mechanism of multivesicular body biogenesis by ESCRT complexes. Nature 2010, 464, 864-873. [CrossRef]

102. Wollert, T.; Wunder, C.; Lippincott-Schwartz, J.; Hurley, J.H. Membrane scission by the ESCRT-III complex. Nature 2009, 458, 172-177. [CrossRef] [PubMed]

103. Tomas, A.; Futter, C.E.; Eden, E.R. EGF receptor trafficking: Consequences for signaling and cancer. Trends Cell Biol. 2014, 24, 26-34. [CrossRef] [PubMed]

104. Tan, X.; Lambert, P.F.; Rapraeger, A.C.; Anderson, R.A. Stress-induced EGFR trafficking: Mechanisms, functions, and therapeutic implications. Trends Cell Biol. 2016, 26, 352-366. [CrossRef] [PubMed]

105. Zwang, Y.; Yarden, Y. p38 MAP kinase mediates stress-induced internalization of EGFR: Implications for cancer chemotherapy. EMBO J. 2006, 25, 4195-4206. [CrossRef] [PubMed]

106. Tomas, A.; Vaughan, S.O.; Burgoyne, T.; Sorkin, A.; Hartley, J.A.; Hochhauser, D.; Futter, C.E. WASH and Tsg101/ALIX-dependent diversion of stress-internalized EGFR from the canonical endocytic pathway. Nat. Commun. 2015, 6, 7324. [CrossRef] [PubMed]

107. Bissig, C.; Gruenberg, J. ALIX and the multivesicular endosome: ALIX in Wonderland. Trends Cell Biol. 2013, 24, 19-25. [CrossRef] [PubMed]

108. Dores, M.R.; Chen, B.; Lin, H.; Soh, U.J.K.; Paing, M.M.; Montagne, W.A.; Meerloo, T.; Trejo, J. ALIX binds a YPX3L motif of the GPCR PAR1 and mediates ubiquitin-independent ESCRT-III/MVB sorting. J. Cell Biol. 2012, 197, 407-419. [CrossRef] [PubMed]

109. Amano, Y.; Yamashita, Y.; Kojima, K.; Yoshino, K.; Tanaka, N.; Sugamura, K.; Takeshita, T. Hrs recognizes a hydrophobic amino acid cluster in cytokine receptors during ubiquitin-independent endosomal sorting. J. Biol. Chem. 2011, 286, 15458-15472. [CrossRef]

110. Luyet, P.-P.; Falguières, T.; Pons, V.; Pattnaik, A.K.; Gruenberg, J. The ESCRT-I subunit TSG101 controls endosome-to-cytosol release of viral RNA. Traffic 2008, 9, 2279-2290. [CrossRef]

111. Shostak, K.; Chariot, A. EGFR and NF-kB: Partners in cancer. Trends Mol. Med. 2015, 21, 385-393. [CrossRef]

112. Grandal, M.V.; Grøvdal, L.M.; Henriksen, L.; Andersen, M.H.; Holst, M.R.; Madshus, I.H.; van Deurs, B. Differential roles of Grb2 and AP-2 in p38MAPK- and EGF-Induced EGFR internalization. Traffic 2012, 13, 576-585. [CrossRef] [PubMed]

113. Hoffman, P.H.; Rajakumar, P.; Hoffman, B.; Heuertz, R.; Wold, W.S.M.; Carlin, C.R. Evidence for intracellular down-regulation of the epidermal growth factor receptor during adenovirus infection by an EGF-independent mechanism. J. Virol. 1992, 66, 197-203. [PubMed]

114. Hoffman, P.; Carlin, C. Adenovirus E3 protein causes constitutively internalized EGF receptors to accumulate in a prelysosomal compartment, resulting in enhanced degradation. Mol. Cell Biol. 1994, 14, 3695-3706. [CrossRef] [PubMed]

115. Tsacoumangos, A.; Kil, S.J.; Ma, L.; Sonnichsen, F.D.; Carlin, C. A novel dileucine lysosomal-sorting-signal mediates intracellular EGF-receptor retention independently of protein ubiquitylation. J. Cell Sci. 2005, 118, 3959-3971. [CrossRef] [PubMed]

116. Barrow-McGee, R.; Kermorgant, S. Met endosomal signalling: In the right place, at the right time. Int. J. Biochem. Cell Biol. 2014, 49, 69-74. [CrossRef] 
117. Kostenko, O.; Tsacoumangos, A.; Crooks, D.M.; Kil, S.J.; Carlin, C.R. Gab1 signaling is regulated by EGF receptor sorting in early endosomes. Oncogene 2006, 25, 6604-6617. [CrossRef] [PubMed]

118. Cunnick, J.M.; Mei, L.; Doupnik, C.A.; Wu, J. Phosphotyrosines 627 and 659 of Gab1 constitute a bisphosphoryl tyrosine-based activation motif (BTAM) conferring binding and activation of SHP2. J. Biol. Chem. 2001, 276, 24380-24387. [CrossRef]

119. Zheng, K.; Kitazato, K.; Wang, Y. Viruses exploit the function of epidermal growth factor receptor. Rev. Med. Virol. 2014, 24, 274-286. [CrossRef]

120. Jindal, S.; Malkovsky, M. Stress responses to viral infection. Trends Microbiol. 1994, 2, 89-91. [CrossRef]

121. Tsutsumi-Ishii, Y.; Nagaoka, I. Modulation of human b-defensin-2 transcription in pulmonary epithelial cells by lipopolysaccharide-stimulated mononuclear phagocytes via proinflammatory cytokine production. J. Immunol. 2003, 170, 4226-4236. [CrossRef]

122. Hayashi, S. Latent adenovirus infection in COPD. Chest 2002, 121, 183S-187S. [CrossRef] [PubMed]

123. Keicho, N.; Elliott, W.M.; Hogg, J.C.; Hayashi, S. Adenovirus E1A upregulates interleukin-8 expression induced by endotoxin in pulmonary epithelial cells. Am. J. Physiol. Lung Cell Mol. Physiol. 1997, 272, L1046-L1052. [CrossRef] [PubMed]

124. Thorne, P.S.; Paul, B. McCray, J.; Howe, T.S.; O’Neill, M.A. Early-onset inflammatory responses in vivo to adenoviral vectors in the presence or absence of lipopolysaccharide-induced inflammation. Am. J. Respir. Cell Mol. Biol. 1999, 20, 1155-1164. [CrossRef] [PubMed]

125. Harrod, K.S.; Mounday, A.D.; Whitsett, J.A. Adenoviral E3-14.7K protein in LPS-induced lung inflammation. Am. J. Physiol. Lung Cell Mol. Physiol. 2000, 278, L631-L639. [CrossRef] [PubMed]

126. Burgert, H.G.; Maryanski, J.L.; Kvist, S. "E3/19K" protein of adenovirus type 2 inhibits lysis of cytolytic T lymphocytes by blocking cell surface expression of histocompability class I antigens. Proc. Natl. Acad. Sci. USA 1987, 84, 1356-1360. [CrossRef] [PubMed]

127. Flomenberg, P.; Gutierrez, E.; Hogan, K. Identification of class I MHC regions which bind to the adenovirus E3-19k protein. Mol. Immunol. 1994, 31, 1277-1284. [CrossRef]

128. Feuerbach, D.; Etteldorf, S.; Ebenau-Jehle, C.; Abastado, J.P.; Madden, D.; Burgert, H.G. Identification of amino acids within the MHC molecule important for the interaction with the adenovirus protein E3/19K. J. Immunol. 1994, 153, 1626-1636. [PubMed]

129. Pahl, H.L.; Baeuerle, P.A. The ER-overload response: Activation of NF-kB. Trends Biochem. Sci. 1997, $22,63-67$. [CrossRef]

130. Choi, S.; Park, Y.S.; Koga, T.; Treloar, A.; Kim, K.C. TNF- $\alpha$ is a key regulator of MUC1, an anti-inflammatory molecule, during airway Pseudomonas aeruginosa infection. Am. J. Respir. Cell Mol. Biol. 2011, 44, 255-260. [CrossRef]

131. Pobezinskaya, Y.L.; Liu, Z. The role of TRADD in death receptor signaling. Cell Cycle 2012, 11, 871-876. [CrossRef]

132. Carmody, R.J.; Maguschak, K.; Chen, Y.H. A novel mechanism of nuclear factor-kappaB regulation by adenoviral protein 14.7K. Immunology 2006, 117, 188-195. [CrossRef] [PubMed]

133. Ye, J.; Xie, X.; Tarassishin, L.; Horwitz, M.S. Regulation of the NF- $k B$ activation pathway by isolated domains of FIP3/IKK $\gamma$, a component of the IkB- $\alpha$ kinase complex. J. Biol. Chem. 2000, 275, 9882-9889. [CrossRef] [PubMed]

134. Machitani, M.; Yamaguchi, T.; Shimizu, K.; Sakurai, F.; Katayama, K.; Kawabata, K.; Mizuguchi, H. Adenovirus vector-derived VA-RNA-mediated innate immune responses. Pharmaceutics 2011, 3, 338-353. [CrossRef] [PubMed]

135. Yamaguchi, T.; Kawabata, K.; Kouyama, E.; Ishii, K.J.; Katayama, K.; Suzuki, T.; Kurachi, S.; Sakurai, F.; Akira, S.; Mizuguchi, H. Induction of type I interferon by adenovirus-encoded small RNAs. Proc. Natl. Acad. Sci. USA 2010, 107, 17286-17291. [CrossRef] [PubMed]

136. Hoffman, P.; Yaffe, M.B.; Hoffman, B.L.; Yei, S.; Wold, W.S.M.; Carlin, C. Characterization of the adenovirus E3 protein that down-regulates the epidermal growth factor receptor. J. Biol. Chem. 1992, 267, 13480-13487. [PubMed]

137. Crooks, D.; Kil, S.J.; McCaffery, J.M.; Carlin, C. E3-13.7 integral membrane proteins encoded by human adenoviruses alter epidermal growth factor receptor trafficking by interacting directly with receptors in early endosomes. Mol. Biol. Cell 2000, 11, 3559-3572. [CrossRef] [PubMed] 
138. Cianciola, N.L.; Greene, D.J.; Morton, R.E.; Carlin, C.R. Adenovirus RIDa uncovers a novel pathway requiring ORP1L for lipid droplet formation independent of NPC1. Mol. Biol. Cell 2013, 24, 3309-3325. [CrossRef] [PubMed]

139. Cianciola, N.L.; Crooks, D.; Shah, A.H.; Carlin, C. A tyrosine-based signal plays a critical role in the targeting and function of adenovirus RID \{alpha\} protein. J. Virol. 2007, 81, 10437-10450. [CrossRef]

140. Van der Kant, R.; Fish, A.; Janssen, L.; Janssen, H.; Krom, S.; Ho, N.; Brummelkamp, T.; Carette, J.; Rocha, N.; Neefjes, J. Late endosomal transport and tethering are coupled processes controlled by RILP and the cholesterol sensor ORP1L. J. Cell Sci. 2013, 126, 3462-3474. [CrossRef]

141. Johansson, M.; Rocha, N.; Zwart, W.; Jordens, I.; Janssen, L.; Kuijl, C.; Olkkonen, V.; Neefjes, J. Activation of endosomal dynein motors by stepwise assembly of Rab7-RILP-p150Glued, ORP1L, and the receptor \{beta\}111 spectrin. J. Cell Biol. 2007, 12, 459-471. [CrossRef]

142. Zhao, K.; Ridgway, N.D. Oxysterol-binding protein-related protein $1 \mathrm{~L}$ regulates cholesterol egress from the endo-lysosomal system. Cell Rep. 2017, 19, 1807-1818. [CrossRef] [PubMed]

143. Cianciola, N.L.; Chung, S.; Manor, D.; Carlin, C.R. Adenovirus modulates Toll-like receptor 4 signaling by reprogramming ORP1L-VAP protein contacts for cholesterol transport from endosomes to the endoplasmic reticulum. J. Virol. 2017, 91, e01904-16. [CrossRef] [PubMed]

144. Vinogradova, O.; Carlin, C.R.; Sonnichsen, F.D.; Sanders, C.R. A membrane setting for the sorting motifs present in the adenovirus E3-13.7 protein which down-regulates the epidermal growth factor receptor. J. Biol. Chem. 1998, 273, 17343-17350. [CrossRef] [PubMed]

145. Cianciola, N.L.; Carlin, C.R. Adenovirus RID- $\alpha$ activates an autonomous cholesterol regulatory mechanism that rescues defects linked to Niemann-Pick disease type C. J. Cell Biol. 2009, 187, 537-552. [CrossRef] [PubMed]

146. Guan, X.; Fierke, C.A. Understanding protein palmitoylation: Biological significance and enzymology. Sci. China Chem. 2014, 54, 1888-1897. [CrossRef] [PubMed]

147. Shah, A.H.; Cianciola, N.L.; Mills, J.L.; Sonnichsen, F.D.; Carlin, C. Adenovirus RID $\alpha$ regulates endosome maturation by mimicking GTP-Rab7. J. Cell Biol. 2007, 179, 965-980. [CrossRef] [PubMed]

148. Guerra, F.; Bucci, C. Multiple roles of the small GTPase Rab7. Cells 2016, 5, 34-40. [CrossRef]

149. Lin, X.; Zhang, J.; Chen, L.; Chen, Y.; Xu, X.; Hong, W.; Wang, T. Tyrosine phosphorylation of Rab7 by Src kinase. Cell Signal. 2017, 35, 84-94. [CrossRef]

150. McNees, A.L.; Garnett, C.T.; Gooding, L.R. The adenovirus E3 RID complex protects some cultured human T and B lymphocytes from Fas-induced apoptosis. J. Virol. 2002, 76, 9716-9723. [CrossRef]

151. Hilgendorf, A.; Lindberg, J.; Ruzsics, Z.; Honing, S.; Elsing, A.; Lofqvist, M.; Engelmann, H.; Burgert, H.-G. Two distinct transport motifs in the adenovirus E3 proteins act in concert to down-modulate apoptosis receptors and the epidermal growth factor receptor. J. Biol. Chem. 2003, 278, 51872-51884. [CrossRef]

152. Chin, Y.R.; Horwitz, M.S. Mechanism for removal of tumor necrosis factor receptor 1 from the cell surface by the adenovirus RID $\{$ alpha\}/\{beta\} complex. J. Virol. 2005, 79, 13606-13617. [CrossRef] [PubMed]

153. Hoffman, B.L.; Ullrich, A.; Wold, W.; Carlin, C. Retrovirus-mediated transfer of an adenovirus gene encoding an integral membrane protein is sufficient to down regulate the receptor for epidermal growth factor. Mol. Cell Biol. 1990, 10, 5521-5524. [CrossRef] [PubMed]

154. Blom, T.; Somerharju, P.; Ikonen, E. Synthesis and biosynthetic trafficking of membrane lipids. CSH Perspect. Biol. 2011, 3, a004713. [CrossRef] [PubMed]

155. Van Meer, G.; Voelker, D.; Feigenson, G. Membrane lipids: Where they are and how they behave. Nat. Rev. Mol. Cell Biol. 2008, 9, 112-124. [CrossRef] [PubMed]

156. D'Angelo, G.; Vicinanza, M.; MA, D.M. Lipid-transfer proteins in biosynthetic pathways. Curr. Opin. Cell Biol. 2008, 20, 360-370. [CrossRef] [PubMed]

157. Lev, S. Non-vesicular lipid transport by lipid-transfer proteins and beyond. Nat. Rev. Mol. Cell Biol. 2010, 11, 739-750. [CrossRef] [PubMed]

158. Olkkonen, V.M.; Beaslas, O.; Nissila, E. Oxysterols and their cellular effectors. Biomolecules 2012, 2, 76-103. [CrossRef]

159. Johansson, M.; Lehto, M.; Tanhuanpaa, K.; Cover, T.L.; Olkkonen, V.M. The oxysterol-binding protein homologue ORP1L interacts with Rab7 and alters functional properties of late endocytic compartments. Mol. Biol. Cell 2005, 16, 5480-5492. [CrossRef] 
160. Rocha, N.; Kuijl, C.; van der Kant, R.; Janssen, L.; Houben, D.; Janssen, H.; Zwart, W.; Neefjes, J. Cholesterol sensor ORP1L contacts the ER protein VAP to control Rab7-RILP-p150Glued and late endosome positioning. J. Cell Biol. 2009, 185, 1209-1225. [CrossRef]

161. Chang, T.-Y.; Reid, P.C.; Sugii, S.; Ohgami, N.; Cruz, J.C.; Chang, C.C.Y. Niemann-Pick type C disease and intracellular cholesterol trafficking. J. Biol. Chem. 2005, 280, 20917-20920. [CrossRef]

162. Suzuki, M.; Sugimoto, Y.; Ohsaki, Y.; Ueno, M.; Kato, S.; Kitamura, Y.; Hosokawa, H.; Davies, J.; Ioannou, Y.; Vanier, M.; et al. Endosomal accumulation of Toll-like receptor 4 causes constitutive secretion of cytokines and activation of signal transducers and activators of transcription in Niemann-Pick disease type C (NPC) fibroblasts: A potential basis for glial cell activation in the NPC brain. J. Neurosci. 2007, 27, 1879-1891. [PubMed]

163. Kagan, J.C.; Su, T.; Horng, T.; Chow, A.; Akira, S.; Medzhitov, R. TRAM couples endocytosis of Toll-like receptor 4 to the induction of interferon- $\beta$. Nat. Immunol. 2008, 9, 361. [CrossRef] [PubMed]

164. Yamamoto, M.; Sato, S.; Hemmi, H.; Hoshino, K.; Kaisho, T.; Sanjo, H.; Takeuchi, O.; Sugiyama, M.; Okabe, M.; Takeda, K.; et al. Role of adaptor TRIF in the MyD88-independent Toll-Like receptor signaling pathway. Science 2003, 301, 640-643. [CrossRef] [PubMed]

165. Triantafilou, M.; Miyake, K.; Golenbock, D.T.; Triantafilou, K. Mediators of innate immune recognition of bacteria concentrate in lipid rafts and facilitate lipopolysaccharide-induced cell activation. J. Cell Sci. 2002, 115, 2603-2611. [PubMed]

166. Olsson, S.; Sundler, R. The role of lipid rafts in LPS-induced signaling in a macrophage cell line. Mol. Immunol. 2006, 43, 607-612. [CrossRef]

167. Lusa, S.; Blom, T.S.; Eskelinen, E.L.; Kuismanen, E.; Mansson, J.E.; Simons, K.; Ikonen, E. Depletion of rafts in late endocytic membranes is controlled by NPC1-dependent recycling of cholesterol to the plasma membrane. J. Cell Sci. 2001, 114, 1893-1900. [PubMed]

168. Hiscott, J.; Kwon, H.; Genin, P. Hostile takeovers: Viral appropriation of the NF-kB pathway. J. Clin. Investig. 2001, 107, 143-151. [CrossRef]

169. Shike, H.; Shimizu, C.; Kanegaye, J.; Foley, J.L.; Burns, J.C. Quantitation of adenovirus genome during acute infection in normal children. Pediatr. Infect. Dis. J. 2005, 24, 29-33. [CrossRef]

170. Flint, S.J.; Racaniello, V.R.; Enquist, L.W.; Skalka, A.M. Principles of Virology, 3rd ed.; Flint, S.J., Enquist, L.W., Racaniello, V.R., Eds.; ASM Press: Washington, DC, USA, 2009.

171. Gueret, V.; Negrete-Virgen, J.A.; Lyddiatt, A.; Al-Rubeai, M. Rapid titration of adenoviral infectivity by flow cytometry in batch culture of infected HEK293 cells. Cytotechnology 2002, 38, 87-97. [CrossRef]

172. Moore, J.D.; Potter, A. Pin1 inhibitors: Pitfalls, progress and cellular pharmacology. Bioorganic Med. Chem. Lett. 2013, 23, 4283-4291. [CrossRef]

173. Nagy, P.D.; Strating, J.R.P.M.; van Kuppeveld, F.J.M. Building viral replication organelles: Close encounters of the membrane types. PLoS Pathog. 2016, 12, e1005912. [CrossRef] [PubMed]

174. Oishi, Y.; Spann, N.J.; Link, V.M.; Muse, E.D.; Strid, T.; Edillor, C.; Kolar, M.J.; Matsuzaka, T.; Hayakawa, S.; Tao, J.; et al. SREBP1 contributes to resolution of pro-inflammatory TLR4 signaling by reprogramming fatty acid metabolism. Cell Metab. 2017, 25, 412-427. [CrossRef] [PubMed]

175. Killerby, M.E.; Rozwadowski, F.; Lu, X.; Caulcrick-Grimes, M.; McHugh, L.; Haldeman, A.M.; Fulton, T.; Schneider, E.; Sakthivel, S.K.; Bhatnagar, J.; et al. Respiratory illness associated with emergent human adenovirus genome type 7d, New Jersey, 2016-2017. Open Forum Infect. Dis. 2019, 6, ofz017. [CrossRef] [PubMed]

176. Liu, H.; Fu, J.; Bouvier, M. Allele- and locus-specific recognition of class I MHC molecules by the immunomodulatory E3-19K protein from adenovirus. J. Immunol. 2007, 178, 4567-4575. [CrossRef] [PubMed]

177. Fu, J.; Li, L.; Bouvier, M. Adenovirus E3-19K proteins of different serotypes and subgroups have similar, yet distinct, immunomodulatory functions toward major histocompatibility class I molecules. J. Biol. Chem. 2011, 286, 17631-17639. [CrossRef]

178. Garnett, C.T.; Erdman, D.; Xu, W.; Gooding, L.R. Prevalence and quantitation of species C adenovirus DNA in human mucosal lymphocytes. J. Virol. 2002, 76, 10608-10616. [CrossRef] 
179. Lion, T.; Kosulin, K.; Landlinger, C.; Rauch, M.; Preuner, S.; Jugovic, D.; Potschger, U.; Lawitschka, A.; Peters, C.; Fritsch, G.; et al. Monitoring of adenovirus load in stool by real-time PCR permits early detection of impending invasive infection in patients after allogeneic stem cell transplantation. Leukemia 2010, 24, 706. [CrossRef]

180. Al Qurashi, Y.M.A.; Guiver, M.; Cooper, R.J. Sequence typing of adenovirus from samples from hematological stem cell transplant recipients. J. Med. Virol. 2011, 83, 1951-1958. [CrossRef]

181. Dhingra, A.; Hage, E.; Ganzenmueller, T.; Bottcher, S.; Hofmann, J.; Hamprecht, K.; Obermeier, P.; Rath, B.; Hausmann, F.; Dobner, T.; et al. Molecular evolution of human adenovirus (HAdV) species C. Sci. Rep. 2019, 9, 1039. [CrossRef]

182. Shisler, J.; Yang, C.; Walter, B.; Ware, C.; Gooding, L. The adenovirus E3-10.4K/14.5K complex mediates loss of cell surface Fas (CD95) and resistance to Fas-induced apoptosis. J. Virol. 1997, 71, 8299-8306.

183. Gooding, L.R.; Ranheim, T.S.; Tollefson, A.E.; Aquino, L.; Duerksen-Hughes, P.; Horton, T.M.; Wold, W.S. The 10,400- and 14,500-dalton proteins encoded by region E3 of adenovirus function together to protect many but not all mouse cell lines against lysis by tumor necrosis factor. J. Virol. 1991, 65, 4114-4123. [PubMed]

184. Lion, T. Adenovirus infections in immunocompetent and immunocompromised patients. Clin. Microbiol. Rev. 2017, 27, 441-462. [CrossRef] [PubMed]

185. Heise, C.; Hermiston, T.; Johnson, L.; Brooks, G.; Sampson-Johannes, A.; Williams, A.; Hawkins, L.; Kirn, D. An adenovirus E1A mutant that demonstrates potent and selective systemic anti-tumoral efficacy. Nat. Med. 2000, 6, 1134. [CrossRef]

186. Weigert, M.; Binks, A.; Dowson, S.; Leung, E.Y.L.; Athineos, D.; Yu, X.; Mullin, M.; Walton, J.B.; Orange, C.; Ennis, D.; et al. RIPK3 promotes adenovirus type 5 activity. Cell Death Dis. 2017, 8, 3206. [CrossRef] [PubMed]

187. Tabas, I. Consequences of cellular cholesterol accumulation: Basic concepts and physiological implications. J. Clin. Investig. 2002, 110, 905-911. [CrossRef] [PubMed]

188. Tall, A.R.; Yvan-Charvet, L. Cholesterol, inflammation and innate immunity. Nat. Rev. Immunol. 2015, 15, 104. [CrossRef] [PubMed]

(C) 2019 by the author. Licensee MDPI, Basel, Switzerland. This article is an open access article distributed under the terms and conditions of the Creative Commons Attribution (CC BY) license (http://creativecommons.org/licenses/by/4.0/). 